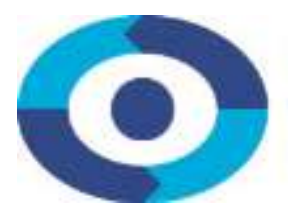

\title{
National Policies for Logistics Services in Chile and Peru: Their Impact and Challenges vis-à-vis the Asia-Pacific Region
}

Adalid García Piña

Instituto de Estudios Internacionales - Universidad de Chile adalid.gpina@gmail.com

\section{Manuel Quindimil}

Sub-Gerente, Área de Relaciones Gubernamentales y Legislativas

Cámara de Comercio Americana del Perú (AmCham Perú)

mquindimil@amcham.org.pe

Recently, logistics services have become one of the most important issues in international trade. The competitiveness in logistics services is essential to get real access to different countries. However, the importance of logistics these services are not negotiated in commercial agreement and not revised for many authors. Peru and Chile have actively participated during the last decades in trade issues, and are now engage in different ongoing negotiation such as WTO Doha Round, the Pacific Alliance, APEC, and TPP amongst others. Both of them depend on trade in a significant percentage of their GDP. The different strategies to enhance commerce between them and worldwide, are definitely fundamental for its development. Asia is known as a paradigm for Latin America, and especially regarding improved logistics competitiveness strategies.

The first section of this paper develops a literature review regarding the different approaches of logistics services definition. The second section will present the Asian approach to this topic, focusing in APEC and ASEAN present discussion. Then we will aim to answer ¿Which are the main modifications that Peru and Chile have done and what is pending? Then through a series of short interviews with the main actors in Chile and Peru we will try to compare the approach form Asia and our countries in order to obtain policy recommendations.

Research for this paper was funded by the Swiss State Secretariat for Economic Affairs under the SECO / WTI Academic Cooperation Project, based at the World Trade Institute of the University of Bern, Switzerland.

SECO working papers are preliminary documents posted on the WTI website (www.wti.org) and widely circulated to stimulate discussion and critical comment. These papers have not been formally edited. Citations should refer to a "SECO / WTI Academic Cooperation Project" paper with appropriate reference made to the author(s).

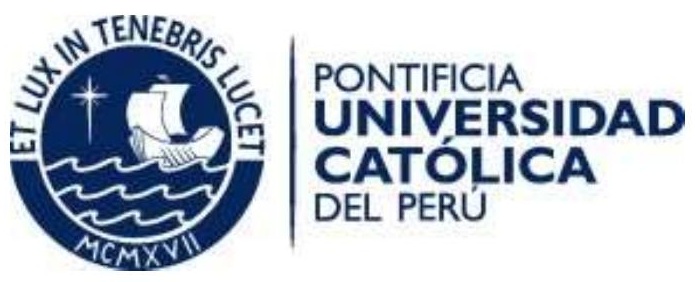




\section{Content}

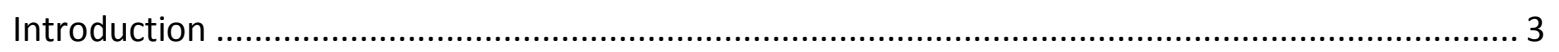

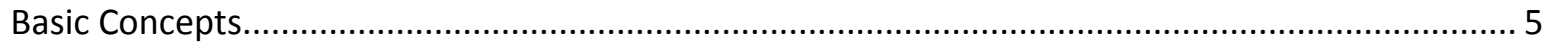

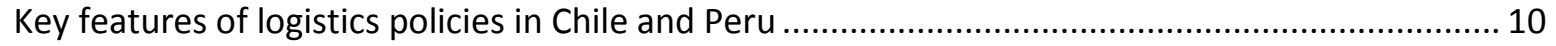

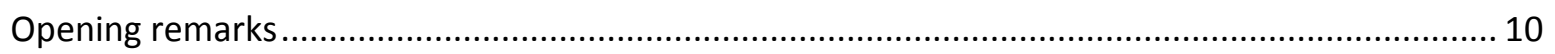

Chile

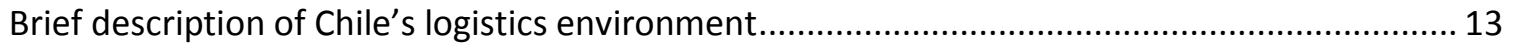

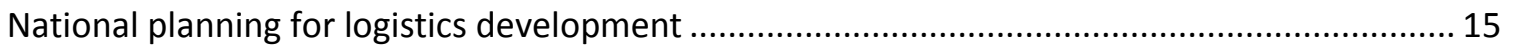

Assessment of logistics services providers........................................................................ 19

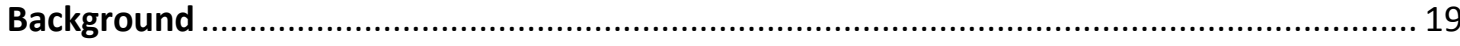

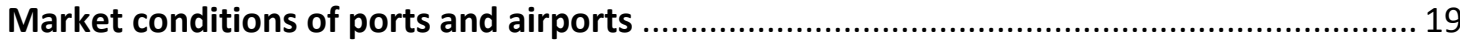

General constrains faced by Chilean logistics services providers ...................................... 22

Regulatory restrictions on logistics services by each operator category ............................ 22

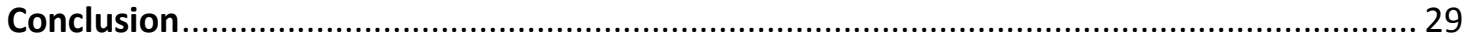

Peru

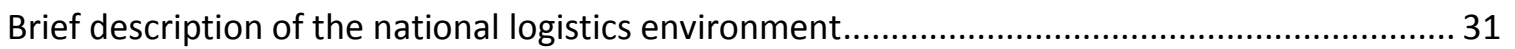

National planning for the development of logistics............................................................... 33

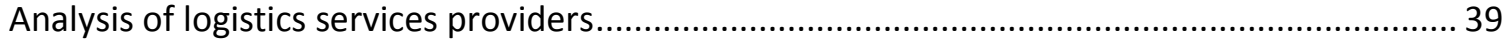

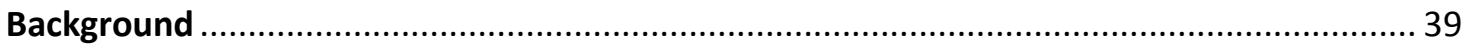

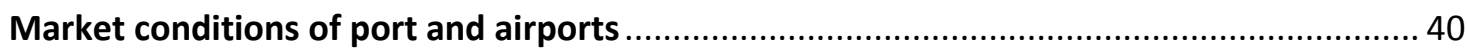

General constrains faced by Peruvian logistics ................................................................. 43

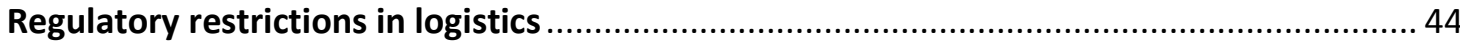

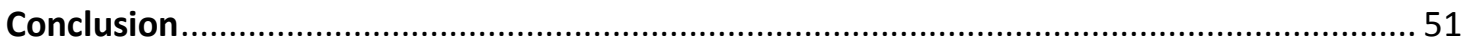

Logistics and Transport Facilitation in the Asia-Pacific Region ................................................. 53

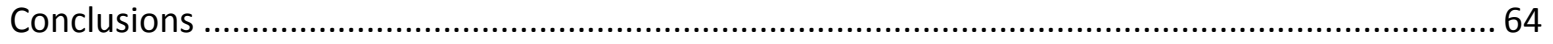

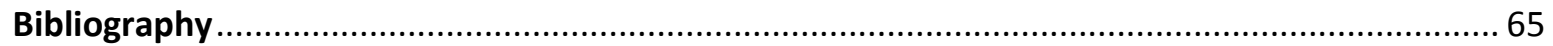




\section{Introduction}

Over the past few decades, globalization has played an important role in world economic performance by increasing market openness and, therefore, international trade.

Because of the proliferation of free trade agreements (FTAs), World Trade Organization (WTO) negotiation rounds, and evolving market needs, international trade has become one of most important drivers of growth. Public and private participants in the international exchange of goods and services have come to realize that trade goes beyond buying and selling, but also involves trade facilitation. Therefore, this has been a crucial issue in WTO negotiation rounds; and significant understandings have been reached between WTO members in this field.

The last 30 years have seen a large reduction in tariffs. However, today the most important deterrents to trade are physical, administrative, and informal obstacles to the movement of goods. Regulations that impinge on the smooth functioning of a global supply chains interfere with trade more than traditional barriers (World Economic Forum, 2013).

Bernard Hoekman and Selina Jackson propose the international supply chain approach, which is based on the notion that international supply chains have become a fundamental feature of global commerce, with goods being processed - and value being added - in the countries that are part of the chain (Hoeckman B. and Jackson S., 2013). This phenomenon leads Richard Baldwin to state that $21^{\text {st }}$ century international commerce is a richer, more complex, and more interconnected set of cross-border flows of goods, investment, technology, services, technicians, managers, and capital. Supply-chain efficiency is not simply about customs facilitation; it also involves the ability to invest in facilities and protect intellectual property, as well as the costs of complying with regulatory requirements regarding health, product safety, security, etc. (Hoeckman B. and Jackson S., 2013).

In this new environment, international trade logistics takes on a leading role. Logistics performance, both in international and domestic trade, is central to growth and competitiveness, and the logistics sector is now recognized as one of the pillars of development. Efficient logistics connects firms to domestic and international markets through reliable supply chains (World Bank, 2016, p. 1). "Logistics services efficiency has become critical for competitiveness. Better logistics performance is strongly associated with trade expansion, export diversification, ability to attract foreign direct investment an economic growth" (Kunaka, Mustra, \& Saez, 2013).

Firstly, to emphasize the importance of promoting logistics services, this article discusses the barriers in the international supply chain. Secondly, an analysis of national logistics systems in Chile and Peru is carried out. With this overview as a starting point, national logistics policies in both countries are described, with emphasis on implementation issues. Understanding the barriers to the provision of logistics is crucial for establishing the challenges to promote these 
services in both countries. Thirdly, regional logistics policies in the Asia-Pacific region is used as a benchmark for both Chile and Peru. Finally, some conclusions are drawn and recommendations are provided to improve public logistics policies. A successful implementation of national logistics plans is likely to lead, soon, to greater consideration of this subject in international negotiations. 


\section{Basic Concepts}

The concepts of logistics and the provision of logistics services are being increasingly integrated into new trade policy. The concept of logistics originates in terms such as "trade facilitation" and "transport facilitation". Historically, the emphasis was on border obstacles and on the concept of trade facilitation. As the interest on the barriers that occur behind the borders increased, the trade agenda began to include issues such as logistics, transportation facilitation, and connectivity.

However, the agenda for the removal of barriers throughout the supply chain in trade forums has not progressed evenly.

As mentioned earlier, as tariff and non-tariff measures were eliminated, the WTO became concerned about issues associated with trade facilitation. The latter was included in the Singapore WTO Ministerial Conference in 1996. Recently, WTO members signed the Trade Facilitation Agreement at the Bali Ministerial Conference in December 2013. However, the latter is limited to regulating measures seeking to eliminate customs restrictions.

In parallel, the academy began to discuss the concept of trade facilitation in a strict sense -i.e., focused on border issues - and broadly, including measures against barriers behind borders. As reported by the Latin American and Caribbean Economic System (SELA from its acronym in Spanish), trade facilitation in the region should be implemented in two stages. The first one consists of administrative reforms to simplify international trade procedures, including regulations for the collection, presentation, and communication of essential data on the traffic of goods.

The second stage has a wider scope. It involves building and improving infrastructure for the transportation of goods from factories to their final market destinations. Ports, airports, highways, and, in general, all facilities necessary for transporting goods swiftly at the minimum possible cost are considered at this stage (SELA-ACICl, 2008).

Within the broad framework of trade facilitation, the concepts of logistics and transport facilitation began to be included in the trade agenda. There is no universally agreed definition of logistics services; and it is often difficult to distinguish accurately all the activities they comprise.

Charles Kunaka, Monica Alina Mustra, and Sebastian Saez (Kunaka, Mustra, \& Saez, 2013) point out that the logistics services industry encompasses several activities that are not always well integrated. These authors state that the logistics sector covers a large set of activities, including all forms of transportation services and all ancillary services related to them, such as distribution, packaging, warehousing, transportation management, and supply chain consulting services, among others. 
For better understanding the scope of logistics services, the United Nations Economic and Social Commission for Asia and the Pacific (UNESCAP) $)^{1}$ suggests an analytical mapping of services traditionally associated with the roles of carrier, warehouse provider, terminal operator, freight forwarder, no-vessel operator, common carrier, and multimodal transport operator. By identifying the services related to each role, it is possible to explore the nature and implications of nontraditional logistics services.

Conforming to the Organization for Economic Co-operation and Development (OECD), "Trade logistics is defined to include the range of services and processes that are involved in moving goods from one country to another. It includes customs and administrative procedures, organization and management of international shipment operations, tracking and tracing, and the quality of transport and information technology infrastructure" (OECD quoted by UNESCAP) (UNESCAP, 2013).

Pursuant to Hamaka and Shepherd, "trade logistics refers to a cluster of related service activities helping firms engage in international trade and which facilitate the development of international supply chains - that bring exporters in one country into contact with consumers in another." These authors split trade logistics into two main components: international and domestic logistics. The former set of activities focuses on the way in which goods move between countries, and the latter focuses on their movement within countries. Another important distinction regarding trade logistics made by these authors is between the "hard" (physical) and "soft" (regulatory) dimensions. The former refers to infrastructure, while the latter covers regulations and services (Hamanaka \& Shepherd, 2015).

The Economic Commission for Latin America and the Caribbean (ECLAC) has recently coined the concept of "advanced logistics". Within this perspective, ECLAC extends the traditional concept of logistics to include an active role of the public sector in the provision of infrastructure services and the regulation and security of trade and transportation, as well as support and competitive strategies conducive to sustainable development. ECLAC also incorporated issues associated with passenger transport within the concept of extended mobility logistics (Jaimurzina, A., Pérez Salas, G. y Sánchez, R., 2015).

Importantly, this paper emphasizes the soft part of the concept of logistics to conduct a study of the development of logistics services, both in Chile and Peru.

Although these services and activities are carried out by private firms for their own benefit, service delivery and the efficiency of supply chains depend on public sector policies and interventions in several domains (World Bank, 2016). As there are considerable infrastructure gaps and a lack of a sector providing modern logistics services in Latin America, government intervention becomes relevant for resolving these market failures.

\footnotetext{
${ }^{1}$ United Nations Economic and Social Commission for Asia and the Pacific (2013), Guide To Key Issues In Development Of Logistics Policy, Division of Transport, http://www.unescap.org/resources/guide-key-issues-development-logisticspolicy
} 
A main problem is the perceived ambiguity of the definition of logistics, which prevents progress in international negotiations about this subject. Hamaka \& Shepard (2015) remark that one of the challenges that policy-makers should address in their efforts to improve logistics is defining its coverage. For these authors, the boundaries of logistics are ambiguous. Even though the WTO has made efforts to define the scope of logistics, it is still challenging to reach a definitive conclusion. Some WTO members WTO find difficulties in identifying all indirect implications or establishing which government services fall within this category. They indicate that the scope of WTO services negotiations is too narrow that they omit government-provided services that are crucial to logistics, such as customs. Logistics services, whose importance is heightened by global production fragmentation, lay outside the WTO terminology in 1994, when GATS were created. ${ }^{2}$ As they gained increasing importance, many countries sought to join WTO negotiations. ${ }^{3}$ These discussions

\footnotetext{
2 Indeed, the GATS did not incorporate such services through a specific classification, within the Services Sectoral Classification List prepared by the GATT Secretariat (W/120) and used for purposes of scheduling liberalization commitments. In 2006, a collective request was advanced by Australia, Canada, Chile, EC, Hong Kong, India, Korea, Malaysia, Mauritius, Mexico, New Zealand, Nicaragua, Norway, Pakistan, Panama, Singapore, Switzerland, Taiwan, Thailand, Turkey and US focusing on logistics services, dividing such services into three tiers: Cargo Freight Logistics Services (services auxiliary to all modes of transport not subject to other plurilateral negotiations; cargo handling services, other cargo handling, storage and warehousing, transport agency services and other auxiliary services); Related Freight Logistics Services ((1) Freight Transport Services: 11. A. Maritime Transport Services, 11.B. Internal Waterways Transport Services, 11.C. Air Transport Services: b. Air freight transport, c. Rental of aircraft with crew; 11. E. Rail Transport Services: Freight transport; 11. F Road Transport Services: b. Freight transport, c. Rental of commercial vehicles with operator or without operator. (2) Other related logistics services: 1.A.e Engineering services, 1.A.f Integrated engineering services, 1.F.e. Technical testing and analysis services, 2. A/B Postal/Courier Services (including express delivery), 4.A Commission Agents' Services, 4. B. Wholesale Trade Services, 4. C. Retailing Services and other supporting services not covered by $11 . \mathrm{H}$ ) and Non-core Freight Logistics Services (computer and related services, packaging, and management consulting and related services).
}

${ }^{3}$ This information is taken from the UNCTAD Secretariat document: Managing the Request-Offer Negotiations under the GATS: Logistics Services. Revised Draft June 2006. (UNCTAD, Managing the Request-Offer Negotiations under the GATS: Logistics services., 2006)

...Proposals on logistics services

42. Hong Kong, China made a specific proposal with respect to the liberalization of logistics services.58 The main objective of its communication is to propose a consolidated list of logistics and related services that could be used by Members in the negotiations to achieve commercially meaningful liberalization of logistics services. The services listed by Hong Kong, China include: (a) freight transportation services; (b) cargo-handling services; (c) storage and warehousing services; (d) customs clearance services; (e) transport agency services; (f) container station and depot services; (g) inventory management services; (h) order processing services; (i) production planning services; and (j) production control services.

43. Hong Kong, China calls upon Members to make substantial market access and national treatment commitments in as many of these sectors as possible. Hong Kong, China also emphasizes the importance of liberalization of maritime transport services as this will lead to further gains from logistics services.

44. A group of eight WTO Members submitted a joint communication on logistics services.59 This proposal is meant to develop further the ideas outlined in the proposals by Hong Kong, China and Switzerland 60 and provide Members with a checklist of logistics services, including core logistics services and supporting services. Based on this checklist, which is to be used as a tool for the negotiations, the group suggests that Members take substantial market access and national treatment commitments. Additional commitments are also encouraged for access to markets to be provided on reasonable and non-discriminatory terms; to address licensing requirements/procedures, technical standards and anticompetitive practices; to allow service suppliers to provide the services on the checklist in combination; to allow for electronic trade administration documents and finally to ensure that procedures and formalities (e.g. for customs inspection and clearance, electronic processing) are not more burdensome than necessary.

45. An even larger group of countries (twenty WTO Members) submitted a joint statement agreeing in principal on the importance of taking commitments in logistics services.61 The sponsoring countries recall the importance of the 
have exposed the difficulties in separating logistics services from transport services when attempting a comprehensive mapping of all activities associated with the supply chain. Especially, pressures in favor of protecting domestic transport services from international competition tend hamper negotiations in this field.

Despite the growing importance of logistics in world trade, recently there has been no significant breakthrough in international negotiations. As stated by Hoekman, WTO negotiations have stagnated because generally they follow a "silo approach"; i.e., specific policy areas or instruments are addressed in isolation in distinct negotiating groups that follow their own modalities and approaches (Hoekman, 2014) . Instead of this negotiating modality, Hoekman proposes a "whole of the supply chain approach"; i.e., negotiations on logistics should bring together a variety of services sectors and sub-sectors that are relevant from a logistics perspective: cargo handling, storage, warehousing, agency services, and related ancillary services, as well as all freight services (air, road, railway, and sea express/courier). Negotiations on this range of services - treated as a "bundle" or a "check-list" - together with parallel discussions on trade facilitation on border management procedures and existing disciplines pertaining to product standards and technical regulations, offer the prospect of addressing many of the policies that affect the operation of global supply chains. However, so far there has not been significant progress in WTO negotiations on logistics - defined as a bundle of services - or in the development of government policies

availability of efficient freight logistics infrastructure and services for global trade and improvement of global economic welfare.

They therefore urge all Members to participate actively in the negotiations with a view to achieving substantial liberalization commitments in logistics services.

46. Finally, five WTO Members submitted a communication on their objectives for the liberalization of logistics services.62 The co-sponsors refer to the joint statement on liberalization of logistics services of February 2005. They also set out their basic objectives for the negotiations. Referring to the checklist of logistics services, they suggest that Members aim, when making offers, to achieve i) new or improved commitments with substantial coverage of services in Core Freight Logistics Services, ii) new or improved commitments covering different modes of transport instrumental to logistics services in Freight Transport Services, iii) new or improved commitments covering a wide range of activities in Other-related Logistics Services, and iv) as far as practicable commitments in Non-Core Freight Logistics Services as well as accompanying additional commitments in order to ensure the effectiveness of commitments in logistics services. Overall, the cosponsors aim for both broadening and deepening of commitments in logistics services in these negotiations by a wide spectrum of Members. Finally, the co-sponsors indicated that they are considering the possibility of pursuing these negotiating objectives through multilateral and plurilateral approaches, supplementary to the bilateral request and offer approach.63 It should be noted that the co-sponsors referred to the flexibility that should be allowed for individual developing Members in taking commitments in different services sectors, considering their development needs and priorities. They also encouraged least-developed Members to consider making liberalization commitments in services across the logistics checklist in view of the potential benefits of liberalization in logistics services to their trade and economic development.

58 Logistics and related services, Communication from Hong Kong, China, 28 March 2001 (CSS/W/68).

59 Logistics services, Communication from Australia; Hong Kong, China; Liechtenstein; Mauritius; New Zealand; Nicaragua; Switzerland and the Separate Customs Territory of Taiwan, Penghu, Kinmen and Matsu, 25 June 2004, TN/S/W/20.

61 Joint Statement on the Liberalization of Logistics Services, Australia; Canada; Chile; Djibouti; the EC; Hong Kong, China; Iceland; Japan; Korea; Liechtenstein; Mauritius; New Zealand; Nicaragua; Norway; Panama; Peru; Singapore; Switzerland; the Separate Customs Territory of Taiwan, Penghu, Kinmen, and Matsu; and the US, 18 February 2005, TN/S/W/34.

62 Objectives for Liberalization of Logistics Services, Communication from Australia; Hong Kong, China, Japan, Switzerland and the Separate Customs Territory of Taiwan, Penghu, Kinmen and Matsu, 27 October 2005, (JOB (05)/264.

63 A draft non-paper proposing benchmarks for the logistics services sectors was circulated among the "Friends of Logistics" Group. It provided for specific targets for liberalization in each of the subsectors listed in the logistics checklist. Furthermore, under certain sectors the benchmarks indicate many of modes for which no substantial limitations should be maintained. However, given the decision by WTO Members at the Hong Kong Ministerial Conference not to pursue with sectoral benchmarks this document was later abandoned. 
relevant for the operation of supply chains (Hoekman, A 21st Century Trade Agenda: Global Supply Chains and Logistics Services, s.f.).

As analyzed in Section four, efforts are afoot in the ASEAN Pacific region to design policy options where border measures (trade facilitation) and behind-the-border measures (transport facilitation and logistics) are integrated into a comprehensive view for promoting competitiveness in the region. This agenda, clearly influenced by a supply chain perspective, comprises topics such as economic corridors, connectivity, competitiveness, transport service liberalization, and logistics service promotion. One of the proposals of this article is that, once national policies logistics are consolidated, steps should be taken to harmonize them with negotiations at the regional and multilateral level. 


\section{Key features of logistics policies in Chile and Peru}

\section{Opening remarks}

This section describes briefly the national logistics policies - and their implementation status - in Chile and Peru. Specifically, regulations for logistics service providers in both countries are discussed. The analysis also includes the identification of barriers to the provision of logistics services.

To have an international perspective of the level of competitiveness of logistics services in Chile and Peru, it is useful to know where they stand within the World Bank logistics performance ranking, as well as the main problems and challenges associated with logistics in both countries.

As in all national logistics systems in Latin America, in both countries the system of state agencies associated with logistics is considerably fragmented. What follows is an assessment of this problem from an institutional point of view.

Given the growing importance of logistics as a source of competitiveness in both countries, the reform process has resulted in logistical plans and national documents. The experiences of Chile and Peru are described in this section.

This paper seeks to develop guidelines for logistics services providers in Chile and Peru. Prior to discussing the performance of logistics service providers in Chile and Peru, it is necessary to explain the global trends underpinning the considerable changes in the provision of logistics services in recent years.

It is useful to define the concept of "service provider" used in this paper. The Council of Supply Chain Management Professionals defines Logistics Service Provider (LSP) as any business providing logistics services, including businesses typically referred to as $3 \mathrm{PL}, 4 \mathrm{PL}, 5 \mathrm{LP}$, etc. Services may include provisioning, transportation, warehousing, packaging, etc. ${ }^{4}$ In view of the fragmentation of international production, the role of logistics intermediaries has been transformed to meet the need of outsourcing logistics processes. John Mangan, Chandra Lalwani, Tim Butcher, and Roya Javadpour indicate that, in recent years, providers of logistics services have grown regarding both the scale and scope of the services they provide. Increasingly, many companies no longer perform many of their own logistics activities. Moreover, logistics companies have evolved so that currently they can offer virtually all functions of the supply chain to their customers (Mangan J., Lalwani Ch., Butcher T. and Javadpour, R., 2012).

The University of Manitoba describes the evolution of supply chain intermediaries from the traditional roles of international carriers, customs brokers, and freight forwarders to the development of third-party logistics providers (3PL) (Hickson, A., Wirth, B. and Morales, G., 2008).

\footnotetext{
${ }^{4}$ The Council of Supply Chain Management Professionals Supply Chain Management Terms and Glossary.
} 
Brokers simply arrange import and export documentations associated with customs clearance; and freight forwarders arrange services for transportation and delivery of goods. Freight forwarders can either act as agents or transportation intermediaries (Hickson, A., Wirth, B. and Morales, G., 2008). "As agents, forwarders simply arrange the services for a fee that includes an additional charge to the amount paid out on behalf of their clients. When acting as a transportation intermediary, the forwarder purchases cargo space on specific routes for a fixed price, which is resold to shippers." ${ }^{5}$

"Third-Party Logistics Provider" is defined by the Council of Supply Chain Management Professionals as a firm that provides multiple logistics services for use by customers. Usually these services are integrated, or "bundled" together by the provider. These firms facilitate the movement of parts and materials from suppliers to manufacturers, and finished products from manufacturers to distributors and retailers. The services they provide include transportation, warehousing, cross-docking, inventory management, packaging, and freight forwarding ${ }^{6}$. John Mangan, Chandra Lalwani, Tim Butcher and Roya Javadpour specify 3PL services: transportation, warehousing, pick and pack, light manufacturing, vendor management inventory, customs clearance, trade financing, managing reverse logistics, parts distribution and inventory management (Mangan J., Lalwani Ch., Butcher T. and Javadpour, R., 2012).

Recently, new service providers denominated Fourth-Party Logistics (4PL) operators are emerging in the market. A 4PL operator is an independent, singularly accountable, non-asset based integrator who assembles the resources, capabilities and technology of its own organization and others, including 3PLs, to design, build, and run comprehensive supply chain solutions for customers. ${ }^{7}$ This service provider differs from 3PLs in that: 1) a 4PL organization is often a separate entity established as a joint venture or long-term contract between a primary client and one or more partners; 2) a 4PL organization acts as a single interface between the client and multiple logistics service providers; 3 ) ideally, all aspects of the client's supply chain are managed by the $4 \mathrm{PL}$ organization; and 4) it is possible for a major 3PL provider to form a 4PL organization within its existing structure ${ }^{8}$.

\footnotetext{
${ }^{5}$ Industry Canada, Analysis and Industry Profiles; http://strategis.ic.gc.ca/epic/internet/indsiblogi.nsf/en/pj00023e.html

${ }^{6}$ The Council of Supply Chain Management Professionals Supply Chain Management Terms and Glossary

${ }^{7}$ The Logistics and Supply Management website. Revised on June 14th 2016. http://logisticsmgt.blogspot.pe/2011/11/what-is-difference-between-1pl-2pl-3pl.html

${ }^{8}$ The Council of Supply Chain Management Professionals Supply Chain Management Terms and Glossary
}

The Logistics and Supply Management website includes the Fifth-Party Logistics Provider:

A fifth party logistics provider (5PL) will aggregate the demands of the 3PL and others into bulk volume for negotiating more favorable rates with airlines and shipping companies.

Non-asset based, it will work seamlessly across all disciplines.

The central ethos of 5PL is its commitment to collaboration and to obtaining more resource utilization to achieve savings and open opportunities to secure the best possible solution at minimum cost/carbon etc. http://logisticsmgt.blogspot.pe/2011/11/what-is-difference-between-1pl-2pl-3pl.html This website was consulted on June $14^{\text {th }} 2016$. 
The changing roles of logistics intermediaries make it very difficult to define each participant in the market. Many service providers have been absorbing different logistical functions, which prevents an unambiguous classification of all logistics operators. Additionally, the various logistics service providers are changing their roles as trade practices evolve. For analytical purposes, to standardize the classification of logistics service providers, this paper follows the categories established by the OECD (Sugie K. e., 2015): cargo-handling services, storage and warehouse services, freight transport services, and customs brokerage services.

This article uses the list of barriers on logistics services identified by the OECD Services Trade Restrictiveness Index (STRI) for Logistics Services. In this index, logistics services are grouped in cargo-handling, storage and warehouse, freight transport, and customs brokerage services. The report identifies the following constraints: restrictions on foreign entry, restrictions on the movement of people, other discriminatory measures, barriers to competition, and regulatory transparency (Sugie K. e., 2015). The environment faced by Chilean and Peruvian logistics service providers is analyzed within this framework. ${ }^{9}$

${ }^{9}$ This report defines each group as restrictions the following:

Restrictions on foreign entry: this category contains barriers to foreign ownership and other impediments to market entry for logistics services providers.

Restrictions on the movement of people: restrictions on temporary movement of crew may influence business operations. These restrictions include duration of visa for crew, availability of visas on arrival or visa exemption for temporary entry or transit of crew and multiple entry visas for crew. In customs brokerage services, some countries grant a license to operate only to nationals or residents. This obviously hinders market entry for foreign firms.

Other discriminatory measures: subsides and all its forms are considered. For storage and warehouse services it is referrers to preferential access for national operators in all kind of protocols since administrative paperwork to operational actions.

Barriers to competition: it leads to manipulation of rules in the playing field. Guidelines might have influence over competition in logistics services. For storage and warehouse, the workable hours in facilitation are included in the measure.

Regulatory transparency: communication and publishing of regulatory regimes and administrative process are a prime factor for this measure because it involves previous time to operational actions, considering that time in logistics is equal for money. 


\section{Brief description of Chile's logistics environment}

Solid economic principles over the last decades have located Chile as one of the most successful economies in Latin America. According the OECD, a favorable global environment has contributed significantly to this good performance; i.e., Chile is the world's main copper producer; and for many years it has benefited from an upswing in commodity prices and low international interest rates. Thus, Chile's growth rate has been above the average for OECD countries (OECD, 2015).

Ports and their logistics have been prime factors in the development of export activities in Chile. The "2030 Strategy for Ports and their Logistics" Commission highlights the importance of the logistics sector in the performance of ports; and this blueprint has been instrumental in securing Chile's role as a regional leader in this field (Comisión Estrategia 2030 de Puertos y su Logística, 2015).

Chile's performance in the World Bank's Logistics Performance Index (LPI) ${ }^{10}$ in 2016 (3.25) is better than for the rest of Latin America (2.48), but much lower than for other OECD countries (3.57). Chile is the first Latin American country in the 2016 LPI (position 46). It is important to note that Chile's LPI performance has remained stable over the last five years. Perceptions about the quality of infrastructure in Chile are very positive, as reflected by the fact that none of the market participants surveyed rated it as low or very low (World Bank Domestic LPI, Environment and Institutions: Chile 2016). ${ }^{11}$ The Global Competitiveness Index 2015-2016, where Chile occupies position 48 out of 140 countries in the area of quality of overall infrastructure, confirms this result (World Economic Forum, The Global Competitiveness Report 2015-2016, 2016).

In contrast, Chile's "soft" logistics area does not enjoy equal consideration. Regarding the competence and quality of services, none of the respondents rated Chile's performance in this area as good or very good (World Bank Domestic LPI, Environment and Institutions: Chile 2016).

However, overall Chile has been an example in South America in terms of its international ratings for logistics and international trade. However, it is important to recall that, while Chile is top in the

\footnotetext{
${ }^{10}$ The logistics performance (LPI) is the weighted average of the country scores on the six key dimensions:

1) Efficiency of the clearance process (i.e., speed, simplicity and predictability of formalities) by border control agencies, including customs;

2) Quality of trade and transport related infrastructure (e.g., ports, railroads, roads, information technology);

3) Ease of arranging competitively priced shipments;

4) Competence and quality of logistics services (e.g., transport operators, customs brokers);

5) Ability to track and trace consignments;

6) Timeliness of shipments in reaching destination within the scheduled or expected delivery time.

${ }^{11}$ http://Ipi.worldbank.org/domestic/environment_institutions/2016/C/CHL\#chartarea
} 
region, it remains distant from the performance of Asian and European countries regarding logistics services.

Moreover, despite being the Latin American country best qualified in the field of logistics, Chile faces specific challenges to increase its competitiveness in importing and exporting goods and providing services. One of these challenges is trade logistics.

The Inter-American Development Bank (IADB) underscores Chile's main logistics challenges, mainly the long distances from important destination markets, as well as the fact that the length of the country increases domestic transport costs. It is therefore crucial to deepen some chains by improving specialized infrastructure. (Guerrero, Lucenti, \& Galarza, 2009)

Barriers to logistics might be defined by institutional and geographical factors. Institutional barriers are related to failures in designing, monitoring and implementing public policies associated with logistics. These kinds of barriers are mainly the following:

- Absence of coordination and integration of policies and investments in logistics sectors.

- Lack of common views between the public and private sectors.

- Lack of instruments to encourage higher levels of investment in sectors associated with trade logistics.

- Political difficulties that hamper changes in the distribution of resources at the domestic level, thereby creating competitiveness losses.

On the other hand, geographical barriers have specific technical and physical implications in Chile. The country's main barriers of this kind are the following:

- Part of Chile's territory is separated from the continental area. This creates challenges for trade logistics, particularly the need to improve the integration between Chile's complex southernmost zone and the rest of the country. This implies a huge investment effort, especially building colossal infrastructure works.

- There is a potential for Chile's political disputes with neighboring countries Argentina, Peru, and Bolivia to translate into trade barriers. Certain policies could bring about retaliations, for instance in the form of transportation blockages, thereby affecting an elemental component of trade logistics.

The 2030 Agenda for Port Logistics Development indicates that the logistics-port system depends on multiple public institutions specialized in specific functions, which nonetheless fail to achieve and efficient coordination. The latter is aggravated by the lack of a comprehensive approach and coherent strategies, public policies, and regulations. To resolve this deficit, the document establishes that the modernization of logistics and port networks in Chile requires a robust institutional framework to promote coordination of public services and the various links in the logistics-port chain (Comisión Estrategia 2030 de Puertos y su Logística, 2015). 


\section{National planning for logistics development}

The Logistics Development Division of the Ministry of Transportation and Telecommunications (MTT) oversees the national logistics policy. The MTT coordinates with other Chilean institutions regarding a number subjects like urban roads (with the Strategic Planning Division); interurban roads (with the Ministry of Public Works); documentary management (with the Ministry of Finance); innovation and human resources (with the Ministry of Economy); environmental issues (with the Ministry of the Environment); and budgeting (with the Ministry of Finance) (Michea A. , 2014). Chile's logistics legislation treats together port development and the promotion of railway freight.

The Logistics Development Program (PDL from its acronym in Spanish) was launched in 2010. Its objective is to attain world-class logistics systems for enhancing economic development. It also proposes a vision for encouraging the continuous development of logistics to improve Chile's competitiveness in foreign and domestic trade; promoting policies and projects (including for freight development); and ensuring proper implementation. The plan rests on four pillars: capacity (achieving the necessary infrastructure to ensure adequate cargo movement in the country); competition and competitiveness (promoting a continuous improvement of logistics as a source of competition and competitiveness, including through document management); professionalization and modernization (constructing an attractive transport industry with a modern and dynamic load capacity); and limit externalities (achieving a harmonious interaction between freight transport vehicles and the cities through which they pass).

The priorities of the MTT in this field include the following:

- Master Logistics Plan: aims at creating a consensus document, including with external actors, to agree on measures identified as necessary for improving Chile's foreign trade competitiveness in a range of areas such as infrastructure, processes, information, and technology.

- Logistics Observatory: seeks to deliver and update logistics indicators relevant for different actors in the chain and for public bodies.

- Plan for reducing logistical barriers: pursues to identify and address the main barriers to the development of logistics.

- Updating the relevant regulatory and institutional framework.

The Program was updated in 2015 by the 2030 Agenda for Port Logistics Development. This paper includes five action guidelines closely linked to public policy on logistics: strengthening institutions, bringing logistics to world-class levels, enhancing technological innovation in the logistics sector, and improving the quality of human resources (Comisión Estrategia 2030 de Puertos y su Logística, 2015)

In addition, Michea (Michea A. , 2014) provides guidelines that MTT should have followed since 2014 for developing logistics in many of sectors: 
Ports

Designing integrated infrastructure plans: a national port development plan should ensure nonarbitrary discrimination in the provision of services by state ports, secure a coastline space for future development, and strengthen local port authorities by removing local inefficiency sources in the development of public services and strengthening port-city relations:

- Removing artificial barriers to cabotage.

- Encouraging competitiveness within and between ports.

Railways

Ensuring adequate infrastructure planning: increase train participation in logistics and infrastructure performance, with an aim to duplicate railway transportation to 2020 tons; and improve the regulation system by introducing an environmental evaluation system and restrictions on high-impact trucks.

Trucking

Gathering and consolidating information, creating an observatory, and carrying out prospective registration to develop efficient tools for managing urban truck flows; ensuring energetic efficiency as a focus of change for achieving greater productivity; and implementing technological tools for enhancing planning and corporate management, especially by improving human resources (drivers and managers).

Reforms across sectors

A Logistics Observatory associated with the OECD International Transport Forum; social evaluation methodologies; port community systems through state port systems; a program for supporting competitiveness and logistics innovation; and a logistics master plan.

Even though Chile has already reaped the benefits from greater competitiveness through tariff reduction, the next step is focusing on the logistical costs of export activities (Michea A. , 2014).

In response to this concern, Chile has implemented several programs over the years. As mentioned in previous chapters, the IADB provides basic and complementary elements for a National Logistics System (NLS) (Banco Interamericano de Desarrollo, 2013). Chile's performance regarding logistics has been outstanding among the countries in the region, as its policy has generally been in line with IADB suggestions: 
Basic components

- Infrastructure. Chile's trade logistics is based on the following areas: sea ports, railways, and freight transportation. The most developed area is the port industry; in the opinion of the Ministry of Public Works (Ministerio de Obras Públicas, 2009), logistics support zones allow port terminals to receive, consolidate, store, control, and coordinate loads transported by ground means. These zones are functional in Valparaíso and lquique, two of Chile's most important ports; and similar facilities are being built in Arica, the $6^{\text {th }}$ Region, and Puerto Montt.

Specialized Logistics Infrastructure: Chile has been making efforts to improve this kind of infrastructure. Industrial parks, where most logistics services are available and are located near a hot spot for transportation, are Chile's bet for optimizing trade logistics.

Services. As highlighted by the IADBs, services are provided by specialized operators. Chile has tried to involve enterprises associated with this field in the design of relevant policies by listening to their demands and linking institutional objectives with the interests of private companies. (Banco Interamericano de Desarrollo, 2013)

- Processes.

- Trade facilitation. Chile has worked in policies to reduce administrative formalities that affect international trade and has contributed to reducing costs and operating times considerably.

- International Trade Integrated System. A tool for facilitating import and export formalities. Chile implemented the system in three stages.

Complementary Components

- Legal Framework. Conectando Chile (2013) underscores that Law 19.542 (Port Enterprises Law) laid the foundation for Chile's current legal progress in trade logistics by modernizing the Port Enterprise of Chile, EMPORCHI. Some other regulations regarding competitiveness, telecommunications, and connectivity for passenger and freight, among others areas, have also contributed to improving the legal framework for trade logistics.

- Institutional Framework. As highlighted by (UNASUR, 2012)"in most instances infrastructure is planned by one institution (a ministry, a specialized agency or another government body) and implemented by another. Services tend to be regulated by a third institution that often had no input at the design stage."12

- Financial Framework. As stated by the IADB estimates, 70\% of total investment came from the private sector (Banco Interamericano de Desarrollo, 2013). Chile's Construction

\footnotetext{
${ }^{12}$ UNASUR. (2012). UNASUR: Infrastructure for regional integration. Santiago de Chile: UNASUR
} 
Chamber estimates that US\$36million will be required for period 2014-2023 for port infrastructure and trade logistics. On the other hand, the government has proposed to spend $3.5 \%$ of GDP in public investments to increase and develop infrastructure for trade logistics. (Comisión Estrategia 2030 de Puertos y Logística 2030, 2015)

- Human Resources. Chile is designing policies to enhance the quality of human resources (Comisión Estrategia 2030 de Puertos y su Logística, 2015):

a. The authorities are going beyond Law 20.773 (port labor regulations) and into issues associated with labor security and risk prevention.

b. To enhance labor specialization, the skills of port employees are being assessed; requirements are targeted for 2030, capacity building activities are carried out constantly; and capabilities are subject to certification.

c. Security conditions and technical regulations are emphasized to improve labor performance; and institutional mechanisms are being explored to resolve labor conflicts.

d. Labor security policies are further strengthened through adherence to international standards issued by the International Labor Organization (ILO), the International Maritime Organization (IMO), and the International Organization for Standardization (ISO).

e. Sanitary conditions are being reviewed to improve the life quality standards of freight transportation drivers (including the regulation of working hours), thereby strengthening the logistics chain and minimizing costs.

f. Technical regulations will be issued to strengthen the capacities of drivers and transportation managers.

g. A database for ground transportation in line with European Union Standards will be put in place to guide policies and assess their impact. It is important to promote compliance with environmental obligations by all participants.

From an institutional standpoint, it is crucial to reinforce governance through mechanisms such as a National Port Logistics Authority to ensure greater coordination between ministries and the public at the national and regional levels. The Commission appointed to draft a framework document for this initiative has suggested a new administrative structure for improving governance in terms of logistics. The first step is to create a new undersecretary's office at the MTT to act as National Port Logistics Authority. Secondly, it is convenient to establish a Committee of Ministers on Logistics and Ports, whose function should be to advise the Presidency on policy guidelines governing this field. Lastly, it is necessary to establish a Council for the Promotion of Logistics and Ports as advisory body to the inter-ministerial committee, with an aim to ensure participation in the design and evaluation of public policies by the public and private sectors, including logistics users, employees, universities, and think tanks.

A valuable proposal from the Commission appointed to draft the agenda is to bring together the strategic plans for trade facilitation and logistics development. In this regard, the Commission 
considers it essential to create an inter-ministerial committee for reinforcing coordination and streamlining foreign trade services, thereby strengthening the role and action plans of the Integrated Foreign Trade System (SICEX).

Institutional initiatives include strengthening the logistics observatory and accelerating its implementation. Moreover, the agenda also considers promoting port logistics coordination and PCS (Port Community Systems) nationwide.

In the field of technological innovation in the logistics sector, the agenda suggests the creation of a center of excellence in research on logistics (Comisión Estrategia 2030 de Puertos y su Logística, 2015).

\section{Assessment of logistics services providers}

\section{Background}

The concession process conducted by the Chilean government in recent years and the subsequent participation of private capital and management in the construction of roads, ports and airports has been a positive response to the considerable increase in freight flows (Alog Chile Asociación Logística AG).

Chile's port system has evolved, starting with the government running all operations (state-owned enterprise EMPORCHI). Due to the government's insufficient capability to operate all port operations, the quality of the services provided was very poor and prices where the result of a public monopoly. However, with an aim to improve innovation and efficiency, rules where created for allowing private investment to increase its participation in port operations. In this regard, a regulatory framework has been put in place to increase private sector participation. Public companies perform as authorities by managing port infrastructure only, and leaving berth and cargo handling services out of its duties (Apoyo Consultoria, 2015). Law No. 19.542 created ten state-run port enterprises as legal successors of EMPORCHI. The Law allows port enterprises to perform their duties either directly or through third parties. In the latter case, they do so by granting port concessions, establishing leasing agreements, or creating corporations with domestic or foreign partners. The Law stipulates that the provision of loading, unloading, cargo transfer (from port to vessel and vice versa), and intra-port transport services, insofar as they form part of the purpose for which the enterprises were established, must be carried out by duly qualified persons. Private companies may participate in the provision of these services through port concessions granted under a public tender procedure, in accordance with the Regulations established by Supreme Decree No. 104 (1998) of the MTT. Domestic or foreign individuals or corporations may participate in the bidding process (World Trade Organization, 2015, pp. 142143).

\section{Market conditions of ports and airports}

Chile has 52 ports, of which 10 are state-owned (with seven operated by private companies under concessions). As far as cargo handling is concerned, the most active ports are Quintero, San Antonio, Valparaíso, Huasco, Lirquén, San Vicente, and Mejillones. The volume of freight moved 
through Chilean ports (including transit but excluding cabotage) rose from 83.6 million tons in 2007 to 111.5 million tons in 2013; i.e., a 33\% increase over the period (World Trade Organization, 2015).

The Valparaíso region is one of the main points of access to international trade in South America. Valparaiso hosts three ports, of which two are run by private companies: Valparaíso (Empresa Portuaria Valparaíso, EPV) and San Antonio (Empresa Portuaria San Antonio, EPSA). The third one (Bahía de Quintero) is for other specific purposes.

Operations in Valparaíso are performed by Terminal Portuario Sur (TPS) and EPV/Terminal Cerros. The San Antonio port is operated by San Antonio Internacional STI, EPSA/ Puerto Central, PANUL and EPSA. STI and TPS are competitors, because they offer homogeneous services; their terminals are similar and serve the same kinds of vessels; and they compete for the same market (Apoyo Consultoria, 2015).

The Valparaíso and San Antonio ports are located just $15 \mathrm{~km}$ apart, which make them highly substitutable. By the end of 2010, TPS in Valparaíso reached its maximum Twenty-Foot Equivalent Unit (TEU) capacity; i.e., the investments made previously were not enough to preserve its leadership in the region. As TPS saturated its capacity, its incentive to reduce fees decreased, as it cannot grab a larger participation in the market (Apoyo Consultoria, 2015).

As reported Apoyo Consultoria, when TPS saturated its maximum container movement, it terminated its competition in the Valparaíso region; and since 2010, the focus shifted to the increase in STI's market participation. For users requesting port services, cargo handling is attended only by STI, located in the San Antonio port, as its terminal has a larger capacity (Apoyo Consultoria, 2015).

Market conditions encouraged the vertical and horizontal integration of the two port companies with shipping lines and agencies. STI relates to shipping line CSAV through the SAAM shipping agency, which, in turn, is in partnership with shipping companies worldwide. At the same time, TPS relates to shipping agencies Maritime Agency Overseas Ltda., which serves in various countries around the world, and Mediterranean Shipping Company S.A. Chile (MSC) (Apoyo Consultoria, 2015). Along the same lines, the Catholic University of Valparaíso indicates that the port model and associated maritime transport services have not been without problems in recent times. Two rulings (2006 and 2010), executed between the Economic Prosecutions and the Free Competition Courts, have verified the significant vertical and horizontal integration in the industry, where three economic groups account for $70 \%$ of foreign trade operations (Pontifical Catholic University of Valparaíso, 2011).

A recent assessment of sea transport in Chile recognizes the levels of efficiency achieved by Chilean ports, but points out that their capacity will not be sufficient to absorb the increase in demand created by the expected expansion of the country's foreign trade over the next few years. Therefore, it recommends laying down plans as soon as possible to expand the national port infrastructure. Similarly, a report drafted by a panel of port experts notes that the rapid growth of 
Chile's foreign trade poses a challenge not only for the provision of infrastructure, but also for the entire associated supply chain (Brooks, M.; Pallis, T. and Perkings, S, 2014).

On the other hand, Chile's main airport is based in the capital, Santiago. International Airport Arturo Merino Benitez (SCL, IATA Code) was granted in concession to the company SCL Terminal Aéreo Santiago S.A. Sociedad Concesionaria in 1998. The cargo terminal is divided in four sections:

1. Import terminals: air terminal Depocargo, fast air storage cargo, and AEROSAN airport services.

2. Export terminals: Andes del Sur cargo terminal, AEROSAN airport services, and export international terminal TEISA.

3. Domestic terminal: LAN and SKY Airline Cargo.

4. Global integrator and courier terminal: DHL, Fedex, UPS, TNT, Correos de Chile, Chilexpress, and Expressit.

The most relevant cargo movements are exports: approximately 157 thousand tons arrived at the airport in 2013. Shipments arriving by air have a marked seasonality (March, April, November, and December).

In their report on air cargo terminals in UNASUR airports, Juan Antún and Rodrigo Alarcón (Antún \& Alarcón, 2015) highlight the following aspects of their inspection of SCL:

- A relevant aspect is that the airport concessionaire views the air cargo terminal as a real estate project. It charges the concessionaires of cargo terminals the highest of $12 \%$ of turnover or the rent by $\mathrm{m}^{2}$.

- The current concession contract considers six operators of cargo terminals, but negotiations are underway to allow more operators and increase the offer of services.

- As there is no control over the volumes handled either in the terminals or in transit storage, there are plans for upgrading the information processes to improve supervision and billing operations. Overall, it is necessary to improve management in the new concessions model.

- There are indications that space is insufficient for accommodating the flow of loading vehicles. The infrastructure is inadequate for supporting high seasonality; e.g., when fruit exports soar in November-February, vehicles can be seen wait in lines up to $7 \mathrm{~km}$ long.

- Deficiencies in the control of cargo vehicles result in mala praxis: cargo vehicles taking export loads remain parked in primary waiting areas to obtain import loads.

- $\mathrm{SCL}$ is not yet a hub, but a terminal airport. Not allowing interconnection between other transport means prevents fluent logistics operations.

Even though Chilean legislation is expected to consider multimodal transport operations, the latter have not been developed in practice. 


\section{General constrains faced by Chilean logistics services providers}

The 2030 Strategy for Ports and their Logistics also identifies challenges that Chile might face in its search for greater competitiveness, not only regarding ports but also other logistics trade components (Comisión Estrategia 2030 de Puertos y su Logística, 2015):

- Improving port capacity. Chile's port infrastructure has increased importantly over the last few decades. To enhance the capacity to react to the increase in the size and capabilities of ships, port terminals should be adapted, as well as infrastructure access like roads, railways, and facilities associated with logistics (i.e., storage facilities and warehouses). The entire coastline should be optimized, and adequate planning should be carried out, to secure efficient management in future operations. As it is difficult for the government to assume the cost of providing infrastructure in the short term, Chile should seek to strike a balance between private and state participation in port management, keeping in mind the need to secure fair public access to services and infrastructure, as well as nondiscriminative rates.

- Relieving tensions between ports and cities. Environmental, health, and traffic issues usually arise about works carried out for improving ports and logistics. The main challenge is to close such institutional deficits by striking a consensus between the public sector, companies, and the public.

- Encouraging the development of transportation infrastructure. This is critical for balancing competitiveness and domestic wellness. The public budget dedicated to road infrastructure increased from 1996 to 2005, and resulted in greater private investment to expand the operational capability of ports and airports. However, as international trade continues to expand and creates greater demands, access to Chile's primary routes has collapsed. The government has responded by proposing to use $3.5 \%$ of GDP in public infrastructure.

- Overcoming dispersion and institutional deficits. Ports and their logistics - and logistics facilities in general - need to be properly regulated by public institutions. However, an efficient coordination has never been implemented. The modernization of tangible logistics also requires an institutional upgrading to create a strong regulatory framework.

\section{Regulatory restrictions on logistics services by each operator category}

With some exceptions, logistics service providers operate in a free market environment.

A significant difference with Peru is that, in Chile, logistics service providers are considered exporters of services. ${ }^{13}$

As barriers on logistics services are kept at a minimum, Chile can be considered an open market for logistics operations.

\footnotetext{
${ }^{13}$ Article 12, letter E, № 16 DL 8251974 (Ley del IVA) and Resolution SNA 2511 which establishes the requirements, obligations and control standards for a service to qualify as Export.
} 
The OECD classifies market conditions and barriers faced by logistics operators in the Chilean market into the following categories: foreign entry, restrictions on the movement of people, other discriminatory measures, barriers to competition, and regulatory transparency.

\section{Foreign entry}

The maximum foreign equity is $100 \%$ that is established by Decreto Ley 600 does not limit foreign participation.

In the event of requiring joint ventures, the Law recognizes limited liability companies, partnerships, and limited partnerships. Chilean law does not classify joint ventures separately; they are equivalent to de facto associations of individuals or entities. Partnerships are regulated in the Commerce Code. Law 19.857 enables any individual to constitute a limited company. Foreign branches are not prohibited and there are no other further restrictions.

There are no restrictions on whether board directors or managers should be nationals or residents.

For contracts subscribed before January 2016, DL 600 will continue to apply for screening projects in line with their economic objectives. From that date on, a law establishing a framework for foreign direct investment in Chile will apply and there will be no screening.

There are no quotas for licenses and permits. No specific legislation applies to the road sector.

There are no further conditions on subsequent transfers of capital and investments.

There are not restrictions on cross-border mergers and acquisitions.

There are restrictions on the acquisition and use of land and real estate by foreigners. At the same time, the latter apply only to real estate located in areas close to national borders and deemed strategic for national security. There are limits on real estate acquisition on the frontier zone, defined as land situated within $10 \mathrm{~km}$ from the border and $5 \mathrm{~km}$ from the coast. Governmentowned land located up to $10 \mathrm{~km}$ from the border may only be acquired, leased, or received under any other title by Chilean individuals or entities.

There are no conditions on subsequent transfer of capital and investments. DL 600 is a voluntary and special regime for the entry of capital into the Chilean market.

\section{Restrictions on the movement of people}

The Labor Law (Articles 19-20) requires that at least $85 \%$ of employees in any company with more than 25 contracted employees be Chilean citizens.

Regarding labor market tests, intra-corporate transferees have visas granted subject to work contracts. The practice of a profession, activity, or work contract must be essential or necessary 
for the country's development. Otherwise, there are no requirements for intra-corporate and contractual service suppliers.

Regarding limitations for staying in the country, the time lapse is $\mathbf{2 4}$ months for intra-corporate transferees, contractual services suppliers, and independent service suppliers. All employmentbased visas for residents' subject to a contract are valid for up to two years and may be extended for similar periods. A work contract must contain a clause whereby the employer commits to pay the return fare of the worker. All employment-based residents may apply for permanent residence after two years of residence -Decree Law 1094- (Ley de Extranjeria).

\section{Other discriminatory measure}

Foreign suppliers are not subject to different treatment regarding taxes and eligibility for subsides. Under DL 600, articles 7 and 8 (Foreign Investment Statute), a foreign investor may choose to pay a higher effective overall tax of $42 \%$ instead of the general withholding tax of $35 \%$. This "tax invariability" is fixed for a period of 10 years, which may be extended under certain circumstances to a maximum of 20 years. A foreign investor may waive this special regime and be subject to the general tax legislation, with the same rights, options, and obligations as national investors (Income Tax Law).

In case of public procurement, there are no explicit preferences for local suppliers or any conditions of competition favorable to local firms.

National standards applicable to transport packages deviate from international practice. Foreign firms are not eligible for Authorized Economic Operators Schemes. Finally, multimodal transport is totally allowed in the country.

\section{Barriers to competition}

Decisions by a regulatory body can be appealed. There are no specialized courts in Chile to deal with actions against administrative entities, but instead there are several courts and procedures of review. None of them discriminates explicitly against foreigners.

Separation of accounts is not required for airports, ports, and road facilities; but it is required for railway facilities, as Chile's railway system follows a vertically integrated model. Crosssubsidization it also prohibited only for railway facilities.

Service provision to third parties is allowed as well as multimodal transport.

\section{Regulatory Transparency}

The Law establishes the obligation to communicate to the public any regulations, prior to their entry into force, in the Official Newspaper (Diaro Oficial) and on the relevant websites. 
All bodies of law are open to comments by stakeholders, including foreign suppliers; and the relevant government institutions shall determine the participation modalities. Such institutions shall, upon request or not, identify those matters of interest where public opinion is required.

\section{Cargo handling services}

The provision of cargo services is led by the private sector, since stevedoring, the transfer of cargo from the port to the ship (and vice versa), and porterage in port areas should be carried out by private companies, unless they are not interested in investing in such activities. In that case, the services must be provided by the port state enterprise (principle of subsidiarity) or, if necessary, by the state, by obligations under international treaties. Storage can be undertaken by a port state enterprise, a private company, or both at once. ${ }^{14}$

Regarding the operators responsible for services to the ship and cargo, Chilean law considers general agents, ship agents, stevedoring agents and wharfage companies.

General agents are individuals or companies acting as commercial agents on behalf of a foreign ship owner. Ship agents are defined as Chilean individuals or companies, acting either on behalf of the ship owner for all acts or efforts concerning the care of the ship at the port. Stevedoring agents and wharfage companies are Chilean individuals or companies who perform in whole or in part the mobilization of cargo between the ship and the port facilities or means of overland transport and vice versa. ${ }^{15}$ Agents are required to sign up in the Register of Agents before the maritime authority. ${ }^{16}$

There are some entry barriers for these kinds of logistics service providers. It should be indicated that ten $100 \%$ state-owned Empresas Portuarias dominate activities (administration, operation, development, maintenance, etc.) and property in the port industry. Paragraph 5 of the said Law grants these companies the right to perform cargo-handling services when private parties are not willing to do so. However, in all those state ports, private companies provide cargo-handling services at the berthing front. Finally, for railway facilities, Empresa de los Ferrocarriles del Estado (EFE) is a $100 \%$ state-owned company, but does not provide cargo-handling services in the railway sector, as the company only provides passenger services. Cargo-handling services are provided by private companies (FEPASA and TRASAP) that have access contracts with EFE, to use the railway facilities.

As for barriers to competition, the government does not control firms in any sector:

Airports. There are no state-owned companies in the relevant subsectors.

Ports. Empresas Portuarias are ten $100 \%$ state-owned port companies dedicated to the administration, operation, development and maintenance of ports and terminals, as well as

\footnotetext{
${ }^{14}$ Article 5o Law 18966.

${ }^{15}$ Article 917 of the Commercial Code.

${ }^{16}$ Article 919 of the Commercial Code.
} 
property owned in any capacity. Paragraph 5 of Law 19.542 grants these companies the right to perform cargo-handling services when private parties are not willing to do so. However, in all those state ports, private companies provide the cargo-handling services at the berthing front.

Road facilities. There are no state-owned companies in the relevant subsectors.

Railway facilities. Empresa de los Ferrocarriles del Estado (EFE) is a $100 \%$ state-owned company, but do not operate cargo-handling services in the railway sector, as it only provides passenger services. Cargo-handling services are provided by private companies (FEPASA and TRASAP) that have access contracts with EFE, to use the railway facilities.

Contracts for universal service obligations are assigned on a competitive basis just for ports (the right to exploit services at ports is awarded through concessions to Chilean or foreign companies, and the awards are subject to a bidding process) and railway facilities (the railway system in Chile follows a vertically integrated model).

As mentioned above, in the Chilean market the vertical and horizontal integration between various links of the logistics chain has been questioned for lack of competition and improper payment for nonexistent services. Regarding ship agents, the Free Competition Court (TDLC) sanctioned the top five companies that together handle more than $70 \%$ of exports for "abuse and violations against free competition, including price fixing, abuse of dominant position, predatory pricing and discrimination are arbitrary" (Pontifical Catholic University of Valparaíso, 2011).

\section{Storage facilities and warehouse services}

An extra-port warehouse is defined as a customs warehousing enclosure designed to provide services to third parties, where goods can be stored until they are retired for import, export or other customs destination. ${ }^{17}$

The installation and operation of extra-port warehouses is delivered by direct qualification to any individual or company who requests it and meets the requirements established under the law. The exploitation of bonded warehouses in fiscal property or property owned by the National Customs Service concession is awarded by public tender to applicants meeting at least the same requirements that this article requires for direct qualification. ${ }^{18}$

The space must meet the technical conditions of storage, health, and safety established by the regulations in place. Such enclosures must be located within the jurisdictional territory of the customs to which they are related. Only imported goods that enter the country through the customs may be deposited in them. ${ }^{19}$

Individuals or companies running storage facilities must comply with the following requirements: (i) develop this activity exclusively; (ii) be morally suitable (i.e., must not be convicted of a crime or

\footnotetext{
${ }^{17}$ Article 56 Ordenanza de Aduanas (Customs Ordinance) D.F.L. № 30/2004.

${ }^{18}$ Article 56 Ordenanza de Aduanas (Customs Ordinance) D.F.L. № 30/2004.

${ }^{19}$ Article 56 Ordenanza de Aduanas (Customs Ordinance) D.F.L. № 30/2004.
} 
offense against public order, or hold debt due and unpaid); (iii) be economically reliable (equity greater than or equal to 6.000 Unidades de Fomento, UF); and (iv) submit a guarantee to the National Customs Service. ${ }^{20}$

A storekeeper must also be enabled as such by the Office of the National Director of Customs. ${ }^{21}$

Storage facilities must comply with the following requirements: (i) a minimum area; (ii) an appropriate lighting system; (iii) access roads to the site; (iv) dependencies for customs and other departments or agencies; (v) systems for controlling the entry and exit of goods and trucks; (vi) area for storing goods; (vii) areas for review of import and export cargo, furnished with Roman weighing scales; (viii) area for consolidating and deconsolidating goods; (ix) security systems and surveillance 24 hours a day; $(x)$ space for the storage of goods seized, retained, expressed or presumably abandoned; and (xi) computer information system for the inventory of stored goods; and (xii) registration of documents and communications with the National Customs Service. ${ }^{22}$

In terms of barriers to competition, it should be noted that, contrary to cargo handling services, contracts for universal service obligations are assigned on a competitive basis to all sectors. Airports, ports, road facilities (the exploitation of storage and warehouse services at customs areas) are subject to a competitive bidding procedure under Article 56 of the Customs Ordinance. There is no such process for ordinary warehouses under the generic/horizontal laws and railway facilities (Chile's railway system follows a vertically integrated model).

\section{Freight transport services}

Resolution No. 2750 defines a cargo agent as a domestic or foreign individual or company who, as consignor or consignee of the goods, and upon payment of a fee, manages the loading or unloading of shipments or their international landing. The order also establishes that a freight forwarder is a domestic or foreign individual or company who, while not being the actual carrier, enters a contract for the carriage of goods, upon payment of freight, by outsourcing the provision of sea, air or ground transportation services; and issues master or house bills of lading for the shipments, as appropriate. ${ }^{23}$

Cargo agents and freight forwarders must be properly registered by the customs system. To this end, they must submit documentation about the society, municipal patents, and newly established companies; and present a Request for Initiation of activities to the Internal Revenue Service, as well as information on their economic background, a statement of solvency, and certification that they do not appear in the register of bankruptcies. In addition, they must provide a guarantee to the National Customs Service, consisting of an insurance policy or bank docket, in force for one year, global and renewable annually for the same period, for an amount determined by the

\footnotetext{
${ }^{20}$ Article 56, Ordenanza de Aduanas (Customs Ordinance) D.F.L. № 30/2004.

${ }^{21}$ Article 56, Ordenanza de Aduanas (Customs Ordinance) D.F.L. № 30/2004.

${ }^{22}$ Articles 12 and 25 Decree 1114.

${ }^{23}$ Article 2 Resolution No. 2750.
} 
National Customs conformable to the equity and movement expected to be carried out by the cargo agent or freight forwarder. ${ }^{24}$

Cargo agents and freight forwarders must keep their records circumstantiated (manually or by computer), their files and statements properly processed, their background documentation in order and, in general, documentation for customs operations performed in the lapse of five years. $^{25}$

Foreign freight forwarders are not restricted from undertaking business in the domestic market. They can provide services without geographical limitations, as established by law.

\section{Customs brokerage services}

Customs agents are regulated by the Customs Ordinance. The Customs Law considers customs agents as auxiliary customs professionals licensed to provide services to third parties as managers in the clearance of goods. ${ }^{26}$

Customs agents must comply with the following conditions: (i) be a Chilean individual or company able to hire; (ii) not having been convicted of a crime deserving afflictive punishment; (iii) not being disqualified for public positions; (iv) having undertaken foreign trade studies and having a history of expertise in customs matters; and ( $v$ ) providing a guarantee amounting to no less than 20 Tax Units. ${ }^{27}$

Companies who intend to provide customs services must meet the following requirements: their business names must begin with the phrase "Customs Agency"; a capital of no less than 5,000 UF; certain percentages of capital contributions and profit-sharing; and a term not exceeding five years society, among the main requirements. ${ }^{28}$

Additionally, they must carry a circumstantial record of all the offices in which they intervene; keep full accounting; keep documents for a period of five calendar years; keep track of their assistants; and establish and maintain sureties in force.

Customs brokers are legally and administratively liable for any act or fraudulent or negligent omission that injures or could harm the interests of the Treasury or be contrary to the best service of the State.

Customs agents are considered public employees for all purposes of the Criminal Code. Sanctions for any responsibilities arising from offenses covered by the Customs or other laws (like tax compliance) shall be enforced by Customs.

\footnotetext{
${ }^{24}$ Articles 3 and 5, Resolution No. 2750.

${ }^{25}$ Article 6, Resolution No. 2750.

${ }^{26}$ Article 195 Ordenanza de Aduanas (Customs Ordinance) D.F.L. № 30/2004.

${ }^{27}$ Article 196 Ordenanza de Aduanas (Customs Ordinance) D.F.L. № 30/2004.

${ }^{28}$ Article 198 Ordenanza de Aduanas (Customs Ordinance) D.F.L. № 30/2004.
} 
Regarding barriers to the exercise of this profession, contrary to cargo handling, storage and warehouse keeping or freight forwarding, there is a de facto requirement that customs agents must be Chilean nationals. The legislation states that a licensed customs broker must not be excluded from the management of the company, and his/her involvement should be proportional to his/hers shares in the company (minimum of 51\%). Hence, the legislation requires that the management of a Chilean customs brokerage company be controlled by Chilean nationals.

Self-handling is prohibited, as customs brokers must be Chilean citizens. Geographical restrictions do not apply to providers of customs brokerage services, as the latter are entitled to offer their services at any customs across Chile.

\section{Conclusion}

This section draws some conclusions from the experience of public policies in logistics and the development of providers of such services.

- In terms of logistics, Chile has been ranked by the World Bank as the best in Latin America and the Caribbean region. However, it remains below the competitiveness levels of other OECD countries.

- Given the need to improve export competitiveness, logistics took on a more prominent role. The government drafted two documents together with the private sector (the Logistics Development Program and the 2030 Strategy for Ports and their Logistics), which constitute the roadmap for implementing public policies aimed at strengthening the competitiveness of logistics activities.

- The Chilean approach does not have a global view of logistics services, as it focuses primarily on ports and logistics.

- A robust institutional framework is not yet in place for facilitating the development of public policies based on public-private dialogue.

- The implementation of multimodal transport is not yet a reality in Chile.

- Regarding logistics service providers, the market's considerable vertical and horizontal concentration has created problems affecting competition and price transparency in the services provided.

- In Chile, logistics service providers are primarily regulated by customs.

- Chile considers logistics services as export services, which constitutes a main tool for promoting their development.

- Logistics service providers, such as 3PL, are not governed by a legal body that may facilitate their development in the country.

- Chilean institutions should seek to strike a balance between providing guidelines, executing protocols, and facilitating trade logistics. Pending activities include establishing priorities within the agenda and emphasizing institutional strengthening efforts with an aim to promote logistics plans and put in place policies for facilitating trade and developing logistics in the country. 
- The country should set out to become the main entrance to South American markets. This goal might not be overly difficult to achieve. Chile is business partner to the main economies in Asia through trade agreements. ${ }^{29}$ This is an advantage over other countries in the region. Moreover, Chile's political and economic stability provides an attractive climate for trade. Chile's international trade is well known because of its traceability; and the country offers better freight security conditions for exports than Peru or Colombia.

${ }^{29}$ https://www.direcon.gob.cl/ Chile is business partner with Japan, South Korea, China, Vietnam, Thailand, Malaysia, India, Australia it is also part of the P4 (New Zeeland, Singapore and Brunei Darussalam) and agreements as well as the Trans-Pacific Partnership (Australia, Brunei Darussalam, Canada, United States, Malaysia, Mexico, Japan, New Zeeland, Peru, Singapore y Vietnam) 


\section{Brief description of the national logistics environment}

In conformity with the United Nations Conference on Trade and Development (UNCTAD), while the development of logistics activities is deemed crucial for improving Peru's competitiveness, there are no policies or legal bodies that govern and institutionalize their development in a comprehensive manner. The latter should include initiatives on planning, national and regional coordination, promotion, and technology (UNCTAD, Peru Services Policy Review UNCTAD/DITC/TNCD/2013, 2013). This approach results in modal regulatory fragmentation.

Peru, like the rest of the region, requires a paradigm shift in transport policy. Instead of treating transport modes individually and separated from each other, the country should embrace a multimodal approach to transport policies.

Peru occupies position 69 in the $2016 \mathrm{LPI}$, with a score of 2.89. Its score is above the average for the Latin American region, but Chile (position 46, with a score of 3.25). Peru's LPI position has remained mostly stable, reflecting an absence of significant reforms in recent years.

An accurate evaluation of logistics in Peru requires an assessment of "hard" and "soft" competences. As for the quality of infrastructure in the domestic LPI, $50 \%$ and $100 \%$ of respondents said that the quality of highways and railways, respectively, is poor. Peru presents serious problems in the development of its infrastructure. Peru occupies position 122 (out of 140 countries) in the 2015-2016 Global Competitiveness Index regarding the quality of overall infrastructure. A disaggregation of the index reveals where the most serious infrastructure problems lie: Peru occupies position 111 for roads, 94 for railways, 86 for ports, and 82 for airports, reflecting the need to promote a significant boost national infrastructure (World Economic Forum, The Global Competitiveness Report 2015-2016, 2016).

As for soft competences, the domestic LPI indicates that, in terms of service quality, $100 \%$ of the respondents surveyed said that the quality of air transport services was good or very good. Only $50 \%$ of respondents said that freight forwarding, warehousing, and inspection services were good or very good. Comparatively speaking, the World Bank international LPI score for Peru in logistics competence (2.87) is well above the average of Latin America (2.67), but below Chile (2.97).

The magnitude of Peru's logistical problems is clear and acknowledged by both the government and the private sector. Costs and logistical inefficiencies have been major obstacles for improving Peru's competitiveness in international markets and its insertion into the global supply chains (The World Bank, 2016).

Leaders from the public and private sectors alike generally agree that the country's transport and logistics infrastructure has not kept pace with the high level of economic growth. To address these needs, in 2011 the government launched a plan to invest \$20.5 billion in infrastructure over the 
following five years. Major efforts are currently underway to attract greater private investment. For example, in May 2013 the government declared of national interest and priority the promotion and facilitation of investment in Peru, with special emphasis on procedures and the issue of permits and licenses. ${ }^{30}$

UNCTAD states that the main obstacle for the development of the logistics sector in the country is the lack of adequate support infrastructure (UNCTAD, Peru Services Policy Review UNCTAD/DITC/TNCD/2013, 2013). Moreover, it emphasizes that this deficit is likely to become more serious, given Peru's prospects for increased economic and trade growth. Peruvian logistics operators indicate that one of the main obstacles they face is the lack of access roads to seaports and storage facilities (UNCTAD, Peru Services Policy Review UNCTAD/DITC/TNCD/2013, 2013).

The offer of logistics services in Peru is undiversified, with reduced specialization and quality. Most of it is limited to transport services with low value added (Ministry of Transport and Communications, Inter-American Development Bank and Advanced Logistics Group, 2011).

The limited professionalization of the actors involved in the provision of transport and logistics services, along with the fragmentation of the business units, are major problems in Peru. There is a considerable difference between large formal logistics companies that comply with international quality standards and serve large export and import companies, and small-sized transport operators offering limited value to SME exporters or production companies serving the domestic market. The latter companies do not comply with international quality standards (Ministry of Transport and Communications, Inter-American Development Bank and Advanced Logistics Group, 2011).

In Peru, there is no substantial outsourcing of logistics services. One of the consequences of the lack of sophistication of logistics services is that the market has not developed standard contracts that can serve as a guide for logistics services transactions (Ministry of Transport and Communications, Inter-American Development Bank and Advanced Logistics Group, 2011).

A shortage of trained human resources among providers and users of logistics services has been identified, specifically among small- and medium-sized enterprises.

The use of information and communication systems and new technologies is very low among the actors in Peru's transport and logistics systems. They are limited to large multinational operators who require compliance with certain operation standards.

The lack of information among small and medium users of the system prevents the creation of a transparent market for transport and logistics services. There is no regular and reliable database for the structure of supply, market failures, costs, and reference prices. About this problem, Peru does not have a Logistics Observatory or a similar mechanism for informing Peruvian international trade operators about costs in a regular and reliable fashion (Ministry of Transport and Communications, Inter-American Development Bank and Advanced Logistics Group, 2011).

${ }^{30}$ See Oxford Business Group (2014) 


\section{National planning for the development of logistics}

There are many entities appointed with regulating logistics services simultaneously, which makes it difficult to design a logistics plan. The following public agencies are related to the national logistics policy:

Ministry of Transport and Communications (MTC): responsible for developing the country's transport systems, as well as its communications and telecommunications infrastructure. The MTC oversees both leading and promoting policies aimed at providing efficient road, railway, air and sea transport systems, as well as of concession programs within its field of competence.

Directorate-General for Water Transport: MTC area in charge of proposing transport policies on maritime, river, and lake routes, except for the ones reserved to the Ministry of Defense. It is responsible for overseeing the construction, improvement, expansion, rehabilitation and maintenance of ports within the national port network.

Directorate-General for Roads and Railways: MTC area in charge of regulating the management of the road, bridge and railway infrastructure, as well as monitoring compliance.

Directorate-General for Civil Aviation: specialized unit of MTC in charge of overseeing and inspecting all activities of aircraft operators to ensure air safety.

Directorate-General for Captaincies and Safeguards: responsible for regulating and ensuring the safety of human life and the protection of the environment and natural resources; and preventing any wrongdoing in the sea environment. It is part of the Peruvian navy.

National Port Authority (APN): decentralized public agency of MTC responsible for the development of the national port system, the promotion of private investment in ports, and the coordination of public and private actors involved in port activities and services.

Peruvian Corporation of Airports and Commercial Aviation (CORPAC): state-owned company in charge of the operation, equipment, and conservation of airports that are not under concession to the private sector. It also provides communication, broadcasting, and traffic control services to airports and airfields under concession to the private sector.

Supervisory Agency for Investment in Public Transport Infrastructure (OSITRAN): Specialized public agency attached to the Presidency of the Council of Ministers. It oversees regulating, monitoring, and supervising the activities of public infrastructure markets, as well as supervising the compliance of concession contracts.

National Superintendence of Tax Administration: specialized technical body under the Ministry of Economy and Finance (MEF) whose mission is to promote compliance with tax and customs payments.

Private Investment Promotion Agency (Prolnversión): a public entity attached to MEF, it is responsible for the implementation of national private investment promotion polices. 
Prolnversión's activities include the development of private investment promotion processes for public works and services, through Special Committees and the Investment Promotion Office. Recently, the APN commissioned Prolnversión with promoting the project "Logistics Platform and Truck Parking \& Service Center of the Port of Callao". However, the project was suspended in April 2015.

National Competitiveness Council (CNC): a body attached to MEF in charge of setting strategic priorities and advancing reforms to support competitiveness, as well as coordinating efforts by the public, private, and academic sectors. The CNC's competitiveness agenda comprises the areas of internationalization (including trade facilitation issues), logistics, and transport infrastructure.

Ministry of Production: In charge of formulating, implementing, and supervising all levels of production (industry, manufacturing, and fishing). It enacted the Development Strategy and the National Plan for Productive Diversification. The Multi-Sectoral Commission for Productive diversification created The Logistics Cross-Executive Board for Productive Diversification, which is responsible for facilitating the development of the supply chain.

Ministry of Trade and Tourism (MINCETUR): Defines, directs, implements, coordinates, and oversees Peru's foreign trade and tourism policies. As logistics is a service, MINCETUR's general objective is promoting Peru's image as an exporter of competitive goods and services. One of the MINCETUR's strategies is to implement effective foreign trade facilitation mechanisms to ensure access to and provide financial and physical distribution services under improved quality and pricing standards. MINCETUR'S main task is to prepare the National Strategic Export Plan. The latter's main pillar is trade facilitation and the efficiency of the international supply chain. It emphasizes the need to achieve a competitive position in Pacific Rise and turn Peru into a regional and international logistics reference.

National Institute for the Defense of Competition and the Protection of Intellectual Property Rights (INDECOPI): Specialized public agency that reports to the Presidency of the Council of Ministers. Among other objectives, it promotes fair and honest competition in Peruvian economy

Although Peru does not have either a National Logistics Law or a National Logistics Plan, certain key documents can be regarded as guidelines for the development of infrastructure and logistics services.

The CNC includes topics related to logistics and transport facilitation in the infrastructure strategic plan, including the goals of promoting logistics services, creating logistics activities zones, establishing transport project priorities, and reducing bureaucratic barriers. ${ }^{31}$

Another piece of work that would be a very useful as a kick-off is the Plan for the Development of Transport Logistics Services issued by the MTC, the IADB, and the Advanced Logistics Group in

\footnotetext{
${ }^{31}$ Both documents can be consulted at the website of the Ministry of Transport and Communication: http://www.mtc.gob.pe/portal/ogpp/estudios.html
} 
2011. ${ }^{32}$ This study was complemented by the 2012 Immediate Action Plan prepared by the Ministry of Transport. ${ }^{33}$ Finally, the 2014 Medium- and Long-Term Plan for the Development of Transport Logistics Services is the most recent strategic document in this field ${ }^{34}$ (Ministry of Transport, the IADB and Advanced Logistics Group).

The 2014-2018 Competitiveness Agenda highlights that, consistent with different assessments of the infrastructure gap, even considering the major investments implemented in recent years, the country needs to cover a 20-billion-dollar gap to grow as expected. ${ }^{35}$

The National Competitiveness Agenda underscores that filling this gap implies paving $100 \%$ of the National Road Network (current progress reaches $82 \%$ ); redefining national roads to allow smooth flow of freight; repowering regional ports; consolidating the mass transit system in Lima and Callao; and modernizing airports across the territory, among others (National Competitiveness Council, 2015, p. 66).

The Peru Services Policy Review prepared by UNCTAD states that, to improve the logistics sector, it is important to continue closing the infrastructure gap. To achieve this, it suggests strengthening the privatization process, increasing concessions, and promoting public-private partnerships for infrastructure development, under an appropriate legal framework (UNCTAD, Peru Services Policy Review UNCTAD/DITC/TNCD/2013, 2013).

On the other hand, the performance of logistics services in Peru presents several shortcomings.

The Plan for the Development of Transport Logistics Services proposes: (i) designing a framework for the strategic development of a sustainable and efficient logistics scheme; (ii) defining the necessary resources for developing logistics platforms and integrating elements existing in different transport modes, in order to set up an integrated infrastructure and logistics network on Peruvian territory; (iii) contributing to develop a consolidated logistics and infrastructure offer (Ministry of Transport and Communications, Inter American Development Bank and Advanced Logistics Group, 2014). These potential service centers and value-added logistics activities should be intermodal and located in different strategic nodes.

These guidelines identify the main constraints faced by the transport and logistics systems in Peru.

\footnotetext{
${ }^{32}$ Ministry of Transport and Communications, the Inter-American Development Bank and the Advanced Logistics Group (2011) The Development Plan of the Logistics Services of Transports, Part A- Diagnosis Final Chapter 8, - Annexes, http://www.mtc.gob.pe/estadisticas/files/estudios/Diagn\%C3\%B3stico\%20Final\%20-\%20Anexos.pdf

${ }_{33}$ Ministry of Transport and Communications (2012), Immediate Action Plan, The Development Plan of the Logistics Services of Transports, General Office Planning and Budget, July 2012, https://www.mtc.gob.pe/estadisticas/files/estudios/PAI_MTC_Versi\%C3\%B3n_Final.pdf

${ }^{34}$ Ministry of Transport, the IADB and Advanced Logistics Group (2014) Plan for the Development of Transport Logistics Services Plan of Medium and Long Term.

https://www.mtc.gob.pe/estadisticas/files/estudios/PMLP_MTC\%20Versi\%C3\%B3n\%20Final.pdf

${ }^{35}$ The National Competitiveness Council (2015), The Competitiveness Agenda 2014-2018, Strategic Lines: Logistics infrastructure and transport, http://www.cnc.gob.pe/images/upload/paginaweb/archivo/38/Infraestructura_logistica_transportes.pdf
} 
In consonance of this Plan, Peru's transport and logistics system undermines the country's competitiveness. It meets only partially the needs of the productive sector; limits the connectivity between businesses (especially small and medium enterprises) and domestic and international markets; provides a reduced supply of value-added services; and operates schemes resulting in high logistics costs (Ministry of Transport and Communications, Inter-American Development Bank and Advanced Logistics Group, 2011).

After the influential Plan for the Development of Transport Logistics Services, the MTC issued the Immediate Action Plan, which encompasses the following strategic goals and strategies (Ministry of Transport and Communications, 2012):

- Strengthen associativity and professionalization, as a lever for making Peru's logistics services industry competitive in terms of quality and cost.

- Promote specialization in the transport and logistics industry by adapting the skills and services offered to the specific needs of different productive sectors.

- Ensure progress towards formalizing agents in the transport and logistics sectors, especially small businesses.

- Increase cargo security at every link along the chain, by supporting traceability systems, and building confidence in the logistics and transport operators among the productive sector.

- Enhance the modernization of the sector through innovation and introduction of new technologies for an efficient management of operations and the provision of high value-added services.

- Promote continuous training in the sector operating, management, and business skills, including by establishing a system of certification of professionals in the field of transport and logistics.

- Improve the sector's image by socializing the advantages and benefits from outsourcing transport and logistics processes, as well as the importance of these activities in the daily life of Peruvians.

- Adapting capabilities and institutional processes to the needs of strengthening the transport and logistics sector, making the State a strategic partner in the development of the sector.

- Promote the reduction of negative externalities associated with freight logistics (environmental issues, accidents, road congestion, etc.)

The main strategies (Ministry of Transport and Communications, 2012) identified in the Immediate Action Plan to meet strategic objectives are the following:

$\checkmark \quad$ Quality of service: defines the policy elements associated with the standards and operation schemes, adapted to the requirements of different production and logistics segments. 
$\checkmark \quad$ High investment in infrastructure: outlines all the elements of the National Logistics Policy (NPL) related to the development or improvement of transport networks and nodes of foreign trade in general and, specifically, the design of a national system of logistics platforms.

$\checkmark \quad$ Security in the supply chain: concerns NLP mechanisms to ensure cargo security, with a view to building trust between cargo owners and the adoption of international standards for safe trade.

$\checkmark \quad$ Institutionalization of the logistics sector: concentrates the elements of public policy aimed at simplifying procedures and trade facilitation policies.

$\checkmark \quad$ Corporatization and internationalization of the sector: includes elements relating to strengthening corporate structures, with a view to generating mid-level logistics specialists, involving capacity building for logistics and transport operators. This strategy involves corporate finance practices, internationalization schemes, strengthening the image of the sector, and using union cohesion tools under an environmental and socially responsible perspective.

The last document regarding logistics services is the Medium- and Long-Term Plan for the Development of Transport Logistics Services issued in 2014 (MTC, IADB, and the Advanced Logistics Group). It provides guidelines for Peru's policies for promoting the establishment of an organized logistics support system (Ministry of Transport and Communications, Inter American Development Bank and Advanced Logistics Group, 2014).

From an institutional point of view, this plan represents a specific regulatory framework for the development of logistics services. Building on predecessor plans, this one reiterates that there are no clear rules to empower the government for developing appropriate long-term logistics plans. For this reason, the consultancy mentioned above aims at proposing the need for a specific regulatory framework to resolve the lack of a comprehensive legislation (Ministry of Transport and Communications, Inter American Development Bank and Advanced Logistics Group, 2014). The most important obstacle is the absence of a common vision among the various public and private actors responsible for making decisions affecting the development of a logistics system.

The first step recommended is creating a structure of government to establish a coherent nationwide logistics policy linking all the agencies involved in the development of the logistics system, to enable them to carry out the necessary activities to meet the objectives set out in the logistics plans and policies.

It argues that the new law assigned a key role in the planning and stewardship of logistics policies to MTC, together with MINCETUR and MEF. While the choice of the agencies is correct, to strengthen the design and implementation of a national logistics system, it is better to allocate the head of this institutional architecture to the Presidency of the Council of Ministers. A political commitment as such a high level would accelerate the process by contributing to bringing together all relevant actors. There is consensus among the MTC, the IADB, and the Advanced Logistics Group highlight that there is no effective coordination of public and private interests 
affecting the development of a logistics system; and that this lack of a common vision creates major policy gaps (Ministry of Transport and Communications, Inter American Development Bank and Advanced Logistics Group, 2014).

An important deliverable of this study is a draft national logistics law. The proposed legislation comprises 15 articles divided into five chapters, generally containing the most important aspects for establishing a legal framework for logistics development. These chapters include the General provisions (Chapter I), The National Logistics Policy (Chapter II), The National Logistics Plan (Chapter III), The National Organization of Logistics (Chapter IV), The Logistics Platforms System (Chapter V), and three provisions (Ministry of Transport and Communications, Inter American Development Bank and Advanced Logistics Group, 2014).

Moreover, the research mentioned above includes the components of the institutional design:

- A committee or an instance of coordination and high-level decision: It would be the discussion forum of public and private stakeholders; it would carry out its functions under the guidance of the PCM (COLOCAF)

- An instance of executive coordination: Responsible for monitoring the implementation of the plan and eventually executing directly some specific components. The MTC is in charge through a new Directorate for Logistics, which would coordinate the work of other institutions.

- An instance of monitoring of the logistics system and the impact of the strategy in the national logistics system: it is recommended to give this function to the private sector or a university (Ministry of Transport and Communications, Inter American Development Bank and Advanced Logistics Group, 2014).

Peru requires a new institutional architecture at the national, regional, and municipal level for dealing with topics related to trade facilitation, logistics, transport infrastructure, and related services. This new vision entails the need to coordinate the objectives of public and private stakeholders. Moreover, as it involves many public entities, this also requires enhanced communication within the Peruvian government.

One of the suggestions of this research is that the proposed law will also incorporate the disciplines of trade facilitation. The reason for this proposal is the multiplicity of forums existing in Peru where similar related issues are discussed. The Framework Law on Logistics and Transport (the name could be changed to include trade facilitation issues) would provide an institutional umbrella for fully reviewing the design and implementation of all these matters.

Despite the importance of the documents presented above, progress in implementing a law on the development of logistics services and a national logistics plan has been insignificant. An example of the lack of momentum in the implementation process has been the suspension of the 
concession process of the Logistics Activities Area (ZAL) and Outer Harbor Port of Callao. After three postponements, the pro-integration Committee of Prolnversión informed the suspension of the bidding process for the ZAL. This exposes the disconnection between those who design public policies in terms of logistics and private operators in this field.

The essential problem in Peru is that continuous progress in the reform proposal in terms of logistics is not possible without enacting a Framework Law on Logistics and Transport. The lack of an institutional structure precludes not only the coordination and implementation of actions in the public sector, but also prevents a constructive dialogue between the authorities and the private sector.

\section{Analysis of logistics services providers}

\section{Background}

Peru does not have an updated law governing the activities of logistics service providers. Many logistics service providers are regulated by the legislation on port services ${ }^{36}$. The agents involved in the chain of port services are the following service providers: shipping lines; port administrators; general agents; sea, river and lake transport agents; stevedoring companies; temporary deposits; freight forwarders; customs brokers; logistics operators; and land carriers.

As for port services, the regulatory entities are the MTC and the APN. ${ }^{37}$ Regulation focuses on the services provided at the port. It refers to handling services and cargo transport, including boarding, loading, unloading, transshipment unloading, and storage of goods. Intermediaries providing individualized logistics services are: general agents; sea, river, and lake transport agents; and stevedoring companies.

Regarding port services and related cargo services, the Advanced Logistics Group report, through a study requested by Peru's Ministry of Foreign Trade and the European Union, concludes that there is duplication of tasks and lack of clarity about who should regulate specific port services. Due to vague rules and blurry legislation, companies providing port services do not have clear roles and responsibilities towards the authorities or users. Another conclusion is that license requirements are minimal and there is little monitoring, a situation that results in a high degree of informality in the provision of port services. Additionally, the report suggests that, given the modernization trends in sea transport, vertical integration of port services should be promoted. Lastly, another major difficulty encountered in the provision of port services is the lack of transparency and disclosure of fees charged by different agents and sent to the Port Authority (Advanced Logistics Group, 2009).

Another regulatory body of service providers related to foreign trade is the customs system. Peru's Customs Law (Legislative Decree $N^{\circ} 1053$ and its amendments) expressly regulates foreign trade

\footnotetext{
${ }^{36}$ Supreme Decree № 010-99-MTC, Ministerial Resolution № 259-2003-MTC and Law № 27943 of the National Port System, modified by the Legislative Decree № 1022, regulated by the Supreme Decree № 0032004-MTC.

37 Legislative Decree 707 (1991), Supreme Decree 010-99-MTC and Supreme Decree 016-2005-MTC (2005).
} 
operators; ${ }^{38}$ and recently Legislative Decree № 1235 incorporated as foreign trade operators the managers or concessionaires of ports, airports or land international terminals. It is important to note that the customs regulation of foreign trade operators aims at customs control and not the development of these intermediaries or the promotion of a comprehensive policy for the logistics chain.

Because of this legislative change, Peru's tax administration agency (SUNAT) issued legislation (National Intendancy Resolution No. 10-2016 - SUNAT / 5F0000) to formalize the authorization of foreign trade operators and the requirements for modification, renewal, extension, or revocation of such authorization to simplify customs administration processes. Peru's Customs Law recognizes as foreign trade operators the following companies: owners, shippers, customs brokers, transport and authorized representatives, international freight forwarders, custom warehouses, postal service companies, express delivery companies, duty free enterprises, beneficiaries of aeronautic material use and the authorized economic operator.

Peruvian logistics operators are companies offering services related to the comprehensive management of the supply chain and cargo handling, through own or leased infrastructure. They are a small number of companies and there is no specific regulation for this type of legal entity. The lack of development of logistics operators is reflected in the absence of a trade association for gathering or promoting the development of quality standards. The absence of any regulation of logistics operators clearly indicates the need to establish a modern legislation to promote their development (Ministry of Transport and Communications I.-A. D., 2011).

\section{Market conditions of port and airports}

Taking into consideration that the port terminal of Callao is the transit channel for more than $70 \%$ of load and $90 \%$ of containerized goods into and out of Peru, the main conclusions of this work will be made considering the logistics chain for containerized cargo at the port. ${ }^{39}$ (Apoyo Consultoria, 2015).

In the chain of containerized cargo in Callao Port is recognized that there is vertical integration that could be causing extra costs, especially for small shippers with low bargaining power (Apoyo Consultoria, 2015).

Integrations in the Callao port terminal are recorded by ties of property and contract type between shipping lines and other companies that operate, or provide part or all the logistics chain of port services (Apoyo Consultoria, 2015).

Firstly, as they can provide temporary storage service, port terminals can be considered in all logistics intermediation operations. The company that is domiciled in the country is the one that operates a port or port terminal. Port terminals are responsible for the management of the

\footnotetext{
${ }^{38}$ Title II of the Legislative Decree $\mathrm{N}^{\circ} 1053$ and its amendments, denominated Operators of Foreign Trade.

${ }^{39}$ The port of Callao is divided between three private concession holders. APM Terminals manages the port's northern area, while the southern area is managed by Dubai Ports World. The third concession holder is Mineral Concentrate Terminal, managed by Consorcio Transportadora Callao.
} 
terminals under their charge and the provision of basic services established in their concession contracts (Advanced Logistics Group, 2009). In the case of Peru, for example, private port terminals have alliances with certain shipping lines. There are cases where the shipping line can have a global alliance with (or own) a specific port terminal and carry their vessels berthing only on the associated berthing port. The level of integration or alliance of shipping lines extends to other links in the logistics chain, which has implications for end users or consignees (Apoyo Consultoria, 2015).

Maritime agencies relate to shipping lines by providing services to them. In many cases, this relationship depends on the extent of vertical integration. Maritime agencies oversee coordinating with the port authority and the port when a ship is located next to the mooring; but are also in charge of processing documents for consignees. As stated in to these commissioned works, on the one hand, the maritime agency charges the shipping line that hires it; and, on the other hand, the consignee, who is forced to work with it. This leads to a situation where the end user has no power to negotiate rates charged by maritime shipping line agents (Apoyo Consultoria, 2015).

On the side of the temporary deposits market, while the consignee may decide freely what temporary storage must be used to manage a shipment, there is a strategic alliance between shipping lines and customs warehouses that can strongly influence the decision. On the one hand, shipping lines maintain alliances with temporary deposits that are assigned to receive the load by default. That is, if consignees do not specify the temporary deposits to which their loads are to be taken, this will be sent directly to the temporary deposit it maintains in alliance with the shipping line, although there is the possibility that the deposit is outside the port area (implying higher expenses for the consignee, due to the associated transport costs). On the other hand, shipping lines rent space to temporary deposits for storing empty containers, so that when a shipment needs to be sent with any shipping line, there is an inclination to manage the shipment with the temporary storage that provides the empty container to the shipping company. In both cases, the shipping line chooses the temporary storage; but the one who pays is the consignee (Apoyo Consultoria, 2015).

In line with to Apoyo's report, shipping lines pass on their costs to shippers of cargo by sea freight (Apoyo Consultoria, 2015). There is debate in Peru about levies of maritime agencies to consignees by formalities such as maritime container insurance, administrative expenses, and the issuance, approval and transmission of bills of loading. This controversy has led to the enactment of Law No. 28977 (Law on Trade Facilitation), which envisages the creation on the MTC website of a freeaccess module containing information on port service companies and airport companies dedicated to providing services to customers. The website should include information about services, content, and pricing that port and airport operators make available to users. Despite this legal mandate, this information mechanism still has not been implemented for the benefit of users of foreign trade services.

Another problem that generates friction between service providers and users in the Port of Callao is linked to deposits outside the port area. In Peru, for historical reasons (lack of infrastructure, 
procedures, trade policy, and security), goods arriving to the port used to be moved to other port terminals for the customs process. Until the entry into operation of private port terminal in the south dock operated by Dubai Ports, Callao operated with the Tool Port organizational model of extra-port deposits (Consorcio Modernización Portuaria, 2011). This model worked in conjunction with an import clearance procedure which was processed once the country was arriving steam. From the point of view of private port operators (2010), the port is the natural point of arrival of goods, and where the customs process is carried out. Parallel to this change in the port model, and because of the FTA with the U.S., ${ }^{40}$ Peru promoted the advance clearance of goods. The new Advance Customs Clearance System (SADA) aims to release goods at the point of arrival, without temporary transfer to warehouses or other facilities. Although it is in a transition period regarding the clearance of goods (logistically it is not possible to process $100 \%$ of import clearance procedures due to insufficient own port infrastructure), the intensive use of deposits outside ports is considered a structural inefficiency (Consorcio Modernización Portuaria, 2011).

Consequently, and as reported by these studies conducted in the port of Callao, there is insufficient transparency of prices for services provided by the logistics providers. In addition, despite complaints from users or consignees, commissioned reports have found no restrictions on free competition in the provision of such services (García Cobos, 2005) (Apoyo Consultoria, 2015).

Another circumstance that cannot be ignored, and which is closely linked to logistics service providers, is the debate about air cargo in the Callao airport (Jorge Chávez International Airport). It is argued that there is a strong concentration in the storage service for air cargo offloaded at Jorge Chávez International Airport. Not only there are only two companies that provide these services, but they have exclusive contracts with most airlines, making it very difficult to compete in this market. Additionally, these companies integrate storage services to ground handling and passenger checking. This allows them to provide the three bundled services and implement a system of cross-subsidies through the free provision of ground handling services and the checking of passengers. Since the storage service is paid by consignees, it is they who ultimately subsidize airlines (Universidad del Pacífico, unkwon). The other storage companies cannot provide the service ramp, which constitutes a barrier to entry. In line with the report submitted by Universidad del Pacifico, this results in unjustified charges to consignees for the services contracted by airlines.

\footnotetext{
${ }^{40}$ Article 5.2: Release of Goods

1. Each Party shall adopt or maintain simplified customs procedures for the efficient release of goods to facilitate trade between the Parties.

2. Pursuant to paragraph 1, each Party shall adopt or maintain procedures that:

(a) provide for the release of goods within a period no greater than that required to ensure compliance with its customs laws, and to the extent possible release the goods within 48 hours of arrival;

(b) allow goods to be released at the point of arrival, without temporary transfer to warehouses or other facilities; and

(c) allow importers to withdraw goods from customs before and without prejudice to the final determination by its customs authority of the applicable customs duties,

taxes, and fees.

Consulted USTR website $24^{\text {th }}$ June 2016.

https://ustr.gov/sites/default/files/uploads/agreements/fta/peru/asset_upload_file921_9538.pdf
} 
To solve this problem, the enforcement of RAP 112 is required. This rule provides that expenses associated with delivery to the recipient will be in charge of the carrier; and that conditions should be expressed in the air waybill (Universidad del Pacífico, unkwon) (Ministry of Transport and Communications, Inter-American Development Bank and Advanced Logistics Group, 2011).

Finally, despite having a legislation, multimodal transport has not been developed in the country.

\section{General constrains faced by Peruvian logistics}

As OECD indicates, mode 3 (Commercial presence) and accompanying movement of personnel (mode 4) are the primary mode of supply for logistics services provided at air ports, ports, and other facilities in foreign countries.

Peru is very open to foreign investment. Domestic and foreign investments are generally subject to the same conditions. The Foreign Investment Law automatically authorizes foreign investments in the country; and, once undertaken, they must be registered with Prolnversion. Foreign investors are guaranteed the right to transfer all their capital, dividends or profits derived from their investments out of the country in freely convertible currencies, once the statutory taxes have been paid. Foreign investment in Peru is based on National Treatment and Non-Discrimination Treatment.

Like any Peruvian company, foreign corporations must comply with the following formalities: Taxpayer Register (RUC) number, Municipal Operation Permission (at the corresponding Municipality), Civil Defense favorable report, and registration at the Foreign Investment Registry.

Under the customs legislation in place, an international trade operator should obtain a RUC number and must not have the condition of "not registered" (no habido) ${ }^{41}$.

There are no equity restrictions on foreign companies in Peru.

Regarding service restrictions, Peru establishes some of them in the horizontal commitments in the General Agreement on Trade and Services (GATS) and the list of reservations negotiated in several FTAs, which include some limitations to market access and national treatment.

The Peruvian national treatment limitations cover the investment regime and cross-border trade in services. The first one is established in article 71 of Peru's Constitution and article 13 of Legislative Decree No. 757 (Framework Law for Private Investment Growth). These articles establish that "no foreign national, enterprise constituted under foreign law or enterprise constituted under Peruvian law, and owned in whole or part, directly or indirectly, by foreign nationals may acquire or own, directly or indirectly, by any title, land or water (including mines, forest or energy resources) located within 50 kilometers of the Peruvian border. Exceptions may be authorized by Supreme Decree approved by the Council of Ministers in conformity with law in cases of expressly declared public necessity. For each case of acquisition or possession within the

\footnotetext{
${ }^{41}$ Article 13을 Supreme Decree № 163-2016.
} 
referred area, the investor shall hand in the correspondent request to the relevant Ministry, pursuant to laws in force".

The other one is found in articles 1, 3, 4, 5, and 6 of Legislative Decree No. 689 (Law on the Recruitment of Foreign Workers). According with this ruling, "all employers in Peru, independently of their activity or nationality, shall give preferential treatment to nationals when hiring its employees. Foreign natural persons who are service suppliers and who are employed by a servicesupplying enterprise may supply services in Peru under a written and time-limited employment contract, which may not exceed three years. The contract may be subsequently extended for like periods of time. Service-supplying enterprises must show proof of the company's commitment to train national personnel in the same occupation. Foreign natural persons may not represent more than 20 per cent of the total number of employees of an enterprise, and their pay may not exceed 30 percent of the total payroll for wages and salaries". However, broad exceptions to these hiring restrictions may apply.

This means that horizontal restrictions apply to all categories of logistics services.

\section{Regulatory restrictions in logistics}

After an analysis of barriers to services in general, a description will be made by the logistics services categories.

\section{Cargo - handling services}

Cargo services are defined as the reception of cargo, loading/unloading, customs operations, storage and connection (handling and placement) with ground transportation. ${ }^{42}$

There are many international trade operators who can provide or contract these services on behalf of the end user.

General agencies: General Agencies Load and Chartering Brokers are individuals or companies acting on behalf of a principal, to whom they are linked by a mercantile commission. They are responsible for contracting the shipments that the principal needs to transport to the port or port of destination and to designate the sea, river, lake agencies and companies of rammer in the national ports where the principal's ships arrive. The market entry requirements for the general agencies are:

- The General Directorate of Water Transport of the Ministry of Transport and Communications grants licenses to the general agencies of foreign shipping companies.

- The entity who provides the licenses requests a Municipal Operation Permission.

- General Agencies must necessarily have a minimum capital, fully subscribed and paid, equivalent to 50 tax units (UIT).

\footnotetext{
${ }^{42}$ García Cobos, J. (2005) Study on the conditions of competition in the markets for cargo services at the port of Callao, PQAXIS. A report by the Competition CAN Project prepared for the INDECOPI. http://www.apam-peru.com/documentacion/BIBLIOTECA/estudiocondiciones.pdf
} 
Sea, river and lake agencies: they are the representatives of the shipping (captain, ship-owner, owner, charterer, operator of the ship, general agent) for all operations within the port, mainly those related to cargo services (reception and delivery of the ship, procedures for the movement of loading, document services at the port, etc.).

Maritime agencies must fulfill these market entry requisites:

- Licenses are issued by the National Port Authority and are valid (and renewable) for one year.

- They must present the Municipal Operation Permission.

- They should necessarily maintain a minimum share capital, fully subscribed and paid, equivalent to 30 tax units (UIT) for the maritime agents and 15 UIT for the river and lake agents. They must present either a bank letter of guarantee or surety policy in the amount of US\$30,000 (first category of ports) or US\$15,000 (second category of ports). Licenses are issued by the National Port Authority and are valid (and renewable) for one year.

Informality exists in ship agency services because the requirements that are demanded from them to operate are minimal. At the same time, the lack of control and sanction to the maritime agents on the part of the APN, contributes to the lack of formality of this type of operators.

Stevedoring companies: companies authorized to carry out port operations in the tasks of loading, unloading, transshipment and moving cargo on ships from the dock the ship or vice versa, and on the bay. These companies can be operated by general agents and maritime agents. Additionally, the workers' union can perform stevedoring activities.

These companies must fulfill some market entry conditions:

- Licenses are issued by the National Port Authority and are valid (and renewable) for one year.

- The entity who provides the licenses requests the Municipal Operation Permission.

- They should necessarily maintain a minimum share capital, fully subscribed and paid, equivalent to 20 tax units (UIT).

- They must present either a bank letter of guarantee or a surety policy in the amount of US\$10,000 (first category of ports) or US\$ 6,000 (second category of ports).

- They are required to hire a "Personal Accident Policy Insurance" to cover the risk of labor accidents for the stevedoring workers they hire.

In these kinds of services, there is a national treatment barrier included in Law No. 27866 (Port Labor Law), articles 3 and 7, whereby only Peruvian citizens may register in the Registry of Port Workers. This measure is contrary to the national treatment principle. Peru includes the following reservations: "Only Peruvian citizens may register in the Registry of Port Workers. A port worker is an individual who, subject to a port employer, performs specific services that conduct to tasks related to port work, such as stevedore, "tarjador", "winchero", "gruero", "portalonero", 
"levantador de costado de nave", among others that are established in each port in accordance the regulations of the current law".

\section{Storage and warehouse services}

Peru has the distinction of having extra-port terminals. Extra-port terminals were developed with the aim of resolving the congestion and security of the port of Callao. The increase in container traffic along with the limited storage space terminal ENAPU (former public port operator), created the need to establish retro port areas for charge storage until shipment or delivery to the final customer. The facilities of extra-port terminals are located mainly near the port areas of Callao and Paita (located in northern Peru).

The regulation of customs warehouses (Supreme Decree No. 08-95-EF) divided storage terminals (terminales de almacenamiento) and customs warehouses authorized (depósitos aduaneros autorizados). Storage terminals are intended to deposit the cargo loaded or unloaded, transported by air, sea, land, river, and lake routes. They are considered an extension of the primary zone of the customs jurisdiction, so that they can receive and dispatch merchandises for customs purposes. ${ }^{43}$ Authorized customs warehouses are facilities for storing goods requested by the customs warehousing procedure.

The current Customs Law establishes the figure of "almacenes aduaneros"; i.e., a room for temporary custody of goods whose administration may oversee the customs authority, other public agencies, or individuals or companies, understood as temporary deposits (depósitos temporales) and customs warehouses (depósitos aduaneros) ${ }^{44}$.

Temporary deposits are deposits where goods waiting to be released by the customs authority are temporarily stored. This regime is defined in the Revised Kyoto Convention ${ }^{45}$ as the storing of goods under customs control in premises and enclosed or unenclosed spaces approved by the customs (hereinafter called temporary stores), pending lodgment of the goods declaration. ${ }^{46}$

Customs warehouses are deposit where goods are entered and stored, as requested by the customs warehousing procedure. The Revised Kyoto Convention states that customs warehousing procedure is the customs procedure whereby imported goods are stored under customs control in a designated place (a customs warehouse) without payment of import duties and taxes. These facilities can be private or public. They support only goods entering the country under the regime of deposit; i.e., with the condition of having customs duties and other taxes that are suspended in payment for a maximum period of twelve months.

\footnotetext{
${ }^{43}$ Article 2o Supreme Decree No. 08-95 -EF

${ }^{44}$ Article 20 Legislative Decree No. 1053.

45 Protocol of Amendment of the International Convention on the Simplification and Harmonization of Customs Procedures. World Customs Organization web-site:

http://www.wcoomd.org/en/topics/facilitation/instrument-and-

tools/conventions/pf_revised_kyoto_conv/kyoto_new.aspx

${ }^{46}$ Specific Annex A. Arrival of goods in a Customs territory. The Revised Kyoto Convention
} 
It should be noted that, since 2010, port terminals have been authorized to provide temporary storage service. That means that deposits outside the port are competing with port terminals providing warehouse services.

The market entry requirements for both operators are:

Temporary deposits and customs warehouses must be located at a maximum reasonable distance from an international port, airport or land transportation entrance of goods and exclusive activity of storage facilities. ${ }^{47}$

Peruvian customs establish the following infrastructural obligations for temporary deposits and customs warehouses: minimum facility area; asphalted, improved or upgraded road; data communications system and computer equipment to enable their interconnection with SUNAT; perimeter fence; physical recognition of the customs area; routes of pedestrian and vehicle access; office for the exclusive use of customs; TV monitoring system; and certified scales, among the most important. ${ }^{48}$

Additionally, both temporary deposits and customs warehouses must submit a bank letter of guarantee or surety policy issued by a bank or insurance, authorized by the Superintendence of Banks and Insurance Companies (SBS), in favor of SUNAT as guarantee for customs; ${ }^{49}$ and prove their economic and financial solvency ${ }^{50}$. The legal representatives of temporary deposits and customs warehouses must not have been punished with cancellation for violations of the tax customs rules or convicted with final judgment for customs fraud. ${ }^{51}$

Finally, SUNAT asks temporary deposits and customs warehouses several certifications from different authorities. One of them is the certification issued by the National Institute of Civil Defense, verifying compliance with the basic conditions of infrastructure security and safety equipment. The Municipal Operation Permission must be presented before Peruvian Customs by Customs warehouses operators. The rest of approvals are: the authorization of the National Service of Animal Health, if the customs warehouse receives live animals; Operation Compliance Certificate issued by the Directorate-General of Civil Aviation, in the case of deposits located at airports; and balance calibration certificates issued by INDECOPI. ${ }^{52}$

Regarding the local presence obligation, article 7 of Supreme Decree No. 08-95-EF approves the Regulation of Customs Warehouses. The latter establishes that "only individuals or companies domiciled in Peru may apply for an authorization to operate a customs warehouse". This condition could be considered an exception to the national treatment.

\footnotetext{
${ }^{47}$ Article 30은 Legislative Decree No. 1053.

${ }^{48}$ Regulation of the General Law of Customs Supreme Decree № 010.2009-EF, article 39․

${ }^{49}$ Regulation of the General Law of Customs Supreme Decree № 010.2009-EF, article 42․

${ }^{50}$ Regulation of the General Law of Customs Supreme Decree № 010.2009-EF, article 43ㅇ.

${ }^{51}$ Article 310 Legislative Decree No. 1053.

${ }^{52}$ Regulation of the General Law of Customs Supreme Decree № 010.2009-EF, article 38․
} 
Peru's customs control operational requirements from authorized warehouse services providers. As all foreign trade operators, both types of depots are obliged to maintain and comply with the requirements and conditions in force to operate; keep the documents referred to in this procedure for five (5) years; communicate different circumstances to customs; caution the integrity of security measures placed or verified by the customs authority; facilitate any customs verification or inspection action control; etc. Additional obligations of customs warehouses include: store and guard goods that have supporting documentation; provide information to customs, and keep records. ${ }^{53}$

SUNAT has the power to grant and revoke operators. Peruvian customs authorities can perform periodic assessments of documentation, infrastructure, security and conservation of documentation. If any customs warehouse fails to comply with its obligations, SUNAT may suspend or cancel their licenses. ${ }^{54}$

\section{Customs brokerage services}

Customs agents have become one of the vectors of integration of logistics services in Peru, since they were the first to offer agency services and freight transport (Ministry of Transport and Communications I.-A. D., 2011)

The conditions for market entry of customs agents are determined by SUNAT. The customs agency service can be provided by individuals or companies incorporated for this purpose. Customs agents who are natural persons must submit the title of Customs Agent issued by the SUNAT. ${ }^{55}$ Among other requirements demanded by SUNAT, customs agents must be domiciled in Peru. Such licensing practice is a clear discriminatory measure against foreigners.

Both individuals and legal representatives of companies purporting to be customs agents must be legally registered and be residents in the country. ${ }^{56}$ Again, this measure can be considered as discriminatory against foreign companies.

Because of these national treatment exceptions, Peru includes in its FTAs some reservations to clearing customs services. Only companies established in Peru (no branches) can perform the customs clearance services. The corporate legal representative must be a Peruvian national. The legal representatives to customs for customs clearance service must be resident in Peru and have a customs agent degree issued by the competent authority. For greater certainty, the corporate legal representative is not necessarily the General Manager of the customs clearance enterprises. Additionally, market access discipline is unbound in this kind of services.

SUNAT also requires these kinds of international trade operators to accredit personal assets. Customs agents must prove to SUNAT personal or corporate assets, as appropriate, equivalent to

\footnotetext{
${ }^{53}$ Article 31은 Legislative Decree No. 1053.

${ }^{54}$ Legislative Decree No. 1053 Tenth Section Offences and Penalties

${ }^{55}$ Article 32은 Legislative Decree No. 1053.

${ }^{56}$ Article 32ㅇ Legislative Decree No. 1053.
} 
$0.25 \%$ of total customs duties and other taxes paid in the previous fiscal year, which in no case can be less than fifty thousand dollars of the United States of America $(\$ 50,000)$. In case of a company, a testimony of the public deed of incorporation of the company, duly registered in the Public Records, must be filled in at SUNAT. This testimony must indicate as exclusive corporate purpose the management of international trade operations and corporate assets amounting to no less than US\$50,000. ${ }^{57}$

Both kinds of customs clearing agents must present to Peruvian customs a bank letter of guarantee, surety policy, or nominal guarantee in the amount of one hundred fifty thousand dollars of the United States of America (US $\$ 150000,00) .{ }^{58}$

Customs agents, both in the case of individuals and companies, must submit an affidavit they have not been convicted of intentional customs crimes. ${ }^{59}$

As for the other foreign trade operators, the Peruvian Customs authority regulates that customs agents are required to keep documentation requirements and maintain a certain type of infrastructure. In this regard, customs agents must retain for five (5) years all original documentation and must have an office that meets the following requirements: a) an area no less than $50 \mathrm{~m} 2$, b) a fire safety equipment, and c) data communication systems and computer equipment to enable their interconnection with SUNAT. ${ }^{60}$

SUNAT is the entity that controls and evaluates the performance of customs agents. This authority may carry out assessments as deemed necessary, as well as apply sanctions or suspend and cancel licenses. $^{61}$

In line with the Law of Prevention of Money Laundering and Financing of Terrorism, the SBS requires customs brokers to present information related to operations suspected of money laundering. ${ }^{62}$

\section{Freight transport agency services}

International Freight Agents are defined in Peru as persons who can realize and receive shipments; consolidate and deconsolidate goods; act as operators of multimodal transport subject to the relevant laws; and issue their own documents connected to theirs activities, such as bills of

\footnotetext{
${ }^{57}$ Article 32은 Legislative Decree No. 1053.

${ }^{58}$ Article 32은 Legislative Decree No. 1053.

${ }^{59}$ Article 32은 Legislative Decree No. 1053.

${ }^{60}$ Article 33 Legislative Decree No. 1053

${ }^{61}$ Legislative Decree No. 1053 Tenth Section Offences and Penalties.

${ }^{62}$ Article 8 of Law No. 27693 and its amendment Law No. 28306, contains the details of all those individuals who are required to implement a system of policies and procedures to prevent money laundering and terrorist financing. Among the obligors, it is understood customs agencies.

SBS Resolution No. 2249-2013, through which the Standard for the Prevention of Money Laundering and Terrorist Financing applicable to Customs Agents
} 
loading, air waybills, transport documents, certificates, and the like. ${ }^{63}$ Unlike other foreign trade operators, freight agents are regulated by the Peruvian customs tangentially for such intermediary logistics services. ${ }^{64}$

In parallel, the consolidator companies offer maritime groupage services (NVOCC). These intermediaries operate as wholesale cargo space on regular shipping lines marketed as cargo agents (Ministry of Transport and Communications I.-A. D., 2011).

There are two kinds of International Freight Agents operating in Peru: sea cargo agents and air cargo agents. The market access requirements for freight agents (including both aerial and maritime) are as follows:

The MTC's Directorate-General for Water Transport oversees authorizing, registering, and certifying marine cargo agents.

Air cargo agents are required an authorization issued by the MTC's Directorate-General for Civil Aviation. To obtain authorization, these international operators must comply with the technical standards established by the International Air Transport Association (IATA).

International Freight Agents are required by the Peruvian Customs to present an operating license from the municipality where they carry out their activities. They must present the Register before the MTC. In case of airfreight agents, SUNAT establishes the obligation to present the Conformity Certificate of Operation issued by the Directorate-General for Civil Aviation.

International freight forwarders must keep the documents referred to in this procedure for five (5) years.

There are specific obligations of international freight agents to transmit or deliver to the Customs Administration the cargo manifest (consolidated or deconsolidated), as well as other documents and acts related to the entry and exit of goods, and rectify or incorporate documents related to the cargo manifest. ${ }^{65}$

SUNAT may sanction international freight agents for misreporting or differences between the goods declared and shipped. ${ }^{66}$

${ }^{63}$ Customs glossary, consulted $1^{\text {st }}$ July 2016. https://mef.gob.pe/index.php?option=com glossary\&letter=A\&id=20\&ltemid=101042\&lang=es

${ }^{64}$ Two other laws are mentioned as International Freight Agents. These regulations are:

DECREE No. 014-2011 - SUPREME MTC Regulation Act No. 28583 Reactivation and Promotion Act of the National Merchant Marine, as amended by Law No. 29475 article 72.

Law of civil aviation security № 28404 , first complementary and final disposal.

${ }^{65}$ Article 29o Legislative Decree No. 1053

${ }^{66}$ Article 192ㅇ Legislative Decree No. 1053 
Finally, because of the integration of the logistics chain, logistics operators providing services throughout the chain have made a very gradual and slow appearance in the Peruvian market. Logistics operators are companies offering services related to the comprehensive management of the supply chain and cargo handling, through their own (or leased) infrastructure. Unlike traditional intermediaries' logistics services, logistics operators not only provide services to the foreign trade cargo, but encompass all operations offered to their customers. Logistics operators manage a value-added information flow to optimize the process and reduce delivery times, inventory costs, and inefficiencies in the chain.

There is no such figure under Peruvian law. Very few logistics operators operate in the Peruvian market, nor is there an industry group that can strengthen quality standards and develop selfregulation.

Despite the growing integration of logistics services in Peru, the current legal framework does not allow the provision of such services under the same company name, so the establishment of several companies is needed.

\section{Conclusion}

To conclude on the regulation of intermediaries' logistics services in Peru, the following can be said:

- Peru has a favorable business climate that can facilitate the development of the logistics industry in the country.

- Peru could use its geographical location in the southern cone of South America and the closeness between the Callao port and airport to become a regional hub.

- Practically there are no state-run companies providing logistics services in in Peru. Among other restrictions to trade in services, there are exceptions to the principle of national treatment for the appointment of customs agents and providers of customs storage services. Otherwise, there are few barriers to the movement of individuals performing services in Peru (Mode 4 of GATS).

- However, Peru's legislation for logistics service providers is outdated.

- A consequence of the latter is that there are many regulatory authorities that are, simultaneously, logistics operators, thereby creating a bureaucratic overload. It is essential to put in place a comprehensive regulation for logistics operators.

- Given the recognition of the importance of both domestic and international logistics development, the country has undertaken research works that propose national logistics development plans. However, despite their merits, to date they have not been implemented.

- Peru has serious restrictions in infrastructure, which should trigger an aggressive plan for logistics development. This investment plan must be accompanied by a program to promote the development of logistics providers in the country.

- In the market for logistics services, especially in the port of Callao, a phenomenon of vertical integration is identified. The latter has led some users of these services to 
question certain practices as contrary to free competition. To date, only the competent authorities have determined that there is little transparency in the pricing of the services provided.

- In addition, the implementation of the national development plan for logistics services should aim at bringing as many large national logistics providers as possible within the quality standards of international logistics operators. In parallel, it should seek to formalize small- and medium-sized enterprises in terms of logistics; and provide quality logistics services to small and medium foreign trade players.

- These public policy objectives should be implemented through a series of incentives and legal mechanisms arising from exchanges between the private and public sectors. It would be reasonable to take as example the Chilean experience, where logistics services are considered as exports of services subject to tax incentives.

- A proposal put forward is that logistics operators should have a single window for submitting all the requirements and guarantees demanded by the national and regional governments, to streamline bureaucratic procedures. The Peruvian authorities, instead of regulating all segments of the chain of services, should take a comprehensive view to avoid double standards.

- While there are few 3PL logistics operators in Peru, it would be advisable to set up a framework law or favor self-regulation practices to promote these services in the country.

- As this phenomenon happens in the industry globally, Peru must have enough trained personnel in terms of logistics and promote the use of information technologies in this field. 


\section{Logistics and Transport Facilitation in the Asia-Pacific Region ${ }^{67}$}

Asia-Pacific is one of the most challenging regions in the world in terms of logistics.

Daniel Saslavsky and Ben Shepherd point out that the emergence of international production networks has been particularly marked in East Asia, where parts and components frequently cross borders several times before being assembled into a final product (Saslavsky, D. and Shepherd, B., 2012). These authors consider that the development of the logistics sector can obviously play a key role in promoting greater integration in international production networks.

This phenomenon obliged central and regional governments to assess the performance of transnational enterprises and the availability of "at the border and beyond the border" aspects of their supply chain, notably regarding issues associated with logistics infrastructure, connectivity and regulatory environment (Goh, 2013). Mark Go specifies that a strong link exists between supply chain connectivity and international trade (Goh, 2013).

Notwithstanding the lack of a clear framework for trade facilitation, countries in the Asia-Pacific region have nonetheless advanced from a concept of trade facilitation at the borders to a more comprehensive concept of logistics, transport facilitation, and connectivity. It is important to note that the trade facilitation (TF) agenda of these countries covers both border and behind the border measures to improve simultaneously customs management, logistics, and transport policies, as well as to further competitiveness at both the national and regional levels.

Because of the objective at the government level to integrate companies into the global supply chains, many countries of the Asia-Pacific region have enacted national logistics plans. A comprehensive national logistics policy is required to promote the development of the logistics industry. The following can be mentioned as examples: The Korean Framework Act on Logistics Policies of 2007; The Chinese Five-Year Plan of 2008; The Indonesian National Logistics Blueprint (approved in 2012); The National Logistics Plan of Malaysia (incorporated into the Third Industrial Plan for 2006-2020); and the National Strategy on Logistics for the Kingdom of Thailand (based on a 2014 cabinet decision).

There are different Ministries in charge of developing and monitoring the national logistics plans and strategies in China (Ministry of Transport), Indonesia (Coordination: Minister for Economic Affairs), Malaysia (Ministry of International Trade and Industry), Republic of Korea (Ministry of

\footnotetext{
${ }^{67}$ This section is based on the update of the paper: Peru as a regional hub for trade facilitation and logistics services: Strategic considerations.

Quindimil, M. (2014). Peru as a regional hub for trade facilitation and logistics services: Strategic considerations. SECO Working Paper Working Paper 05/08/2014.

http://www.wti.org/media/filer_public/a8/78/a8785526-b156-49af-a907-

483c45423f93/wti_seco_wp_08_2014.pdf
} 
Land, Transport and Maritime Affairs), and Thailand (National Economic and Social Development Board) (UNESCAP, 2013).

UNESCAP describes the common features of these national logistics plans (UNESCAP, 2013):

- Infrastructure development.

- $\quad$ Streamlining of logistics regulations and policy.

- $\quad$ Acknowledgement that adequate logistics development at the international level has implications for the domestic logistics industries.

- Recognition of the changing nature of logistics service providers, and commit to the development of domestic industry in line with international trends.

- Importance of ICT.

- Skills and qualifications of logistics personnel.

- $\quad$ Promotion of harmonization and minimum standards in the logistics industry.

- New forms of institutional support for the development of the logistics industry.

- $\quad$ Outline the plans for implementation, including timeline and implementing agencies.

The National Logistics plans establish a logistics council/committee with the purpose of coordinating and serving as a focal point for policy matters associated with logistics. The national council/committee may promote policy consistency and coordination between different stakeholders in the logistics system, as well as the streamlining of policy development. It may also serve as monitoring agency for implementing the national strategy. A national logistics council/committee may apply a multiagency approach by including many several public entities. This council/committee may include representatives of the private sector, such as national logistics associations, chambers of commerce, key companies in the field of logistics, and academics and experts in logistics. The work of the council/committee may be enhanced by setting up sub-committees or working groups on topics (UNESCAP, 2013).

Such an approach was developed recently within the Asia-Pacific Economic Cooperation (APEC) ${ }^{68}$ forum, the Association of Southeast Asian Nations (ASEAN), ${ }^{69}$ and various other sub-regional

\footnotetext{
${ }^{68}$ The Asia-Pacific Economic Cooperation (APEC) is a regional economic forum established in 1989 to leverage the growing interdependence of the Asia-Pacific. APEC's 21 members aim to create greater prosperity for the people of the region by promoting balanced, inclusive, sustainable, innovative and secure growth and by accelerating regional economic integration. APEC's members are: Australia, Brunei Darussalam, Canada, Chile, People's Republic of China, Hong Kong, China, Indonesia, Japan, Republic of Korea, Malaysia, Mexico, New Zealand, Papua New Guinea, Peru, The Philippines, Russia, Singapore, Chinese Taipei, Thailand, The United States, and Viet Nam, http://www.apec.org/AboutUs/About-APEC.aspx and http://www.apec.org/About-Us/About-APEC/Member-Economies.aspx

${ }^{69}$ The Association of Southeast Asian Nations, or ASEAN, was established on 8 August 1967 in Bangkok, Thailand, with the signing of the ASEAN Declaration (Bangkok Declaration) by the Founding Fathers of ASEAN, namely Indonesia, Malaysia, Philippines, Singapore and Thailand.

Brunei Darussalam then joined on 7 January 1984, Viet Nam on 28 July 1995, Lao PDR and Myanmar on 23 July 1997, and Cambodia on 30 April 1999, making up what is today the ten Member States of ASEAN.
}

AIMS AND PURPOSES

As set out in the ASEAN Declaration, the aims and purposes of ASEAN are: 
integration schemes, including bilateral FTAs. Recently, the supply chain competitiveness perspective is being negotiated in mega-regional agreements such us the Trans-Pacific Partnership $(\mathrm{TPP})^{70}$ and the Regional Comprehensive Economic Partnership (RCEP) ${ }^{71}$.

Reflecting this new approach, APEC moved from its Trade Facilitation Action Plan (TFAP, 20012010) to a Supply Chain Connectivity Framework Action Plan (UNESCAP 2010-2015). In the TFAP's first phase, which started in 2001, APEC Leaders called for a 5 percent cut in trade transaction

- To accelerate the economic growth, social progress and cultural development in the region through joint endeavors in the spirit of equality and partnership to strengthen the foundation for a prosperous and peaceful community of Southeast Asian Nations;

- To promote regional peace and stability through abiding respect for justice and the rule of law in the relationship among countries of the region and adherence to the principles of the United Nations Charter;

- To promote active collaboration and mutual assistance on matters of common interest in the economic, social, cultural, technical, scientific and administrative fields;

- To aid each other in the form of training and research facilities in the educational, professional, technical and administrative spheres;

- To collaborate more effectively for the greater utilization of their agriculture and industries, the expansion of their trade, including the study of the problems of international commodity trade, the improvement of their transportation and communications facilities and the raising of the living standards of their peoples;

- To promote Southeast Asian studies; and

- To maintain close and beneficial cooperation with existing international and regional organizations with similar aims and purposes, and explore all avenues for even closer cooperation among themselves.

\section{ASEAN COMMUNITY}

The ASEAN Vision 2020, adopted by the ASEAN Leaders on the 30th Anniversary of ASEAN, agreed on a shared vision of ASEAN as a concert of Southeast Asian nations, outward looking, living in peace, stability and prosperity, bonded together in partnership in dynamic development and in a community of caring societies.

At the 9th ASEAN Summit in 2003, the ASEAN Leaders resolved that an ASEAN Community shall be established.

At the 12th ASEAN Summit in January 2007, the Leaders affirmed their strong commitment to accelerate the establishment of an ASEAN Community by 2015 and signed the Cebu Declaration on the Acceleration of the Establishment of an ASEAN Community by 2015.

The ASEAN Community is comprised of three pillars, namely the ASEAN Political-Security Community, ASEAN Economic Community and ASEAN Socio-Cultural Community. Each pillar has its own Blueprint, and, together with the Initiative for ASEAN Integration (IAI) Strategic Framework and IAI Work Plan Phase II (2009-2015), they form the Roadmap for an ASEAN Community 2009-2015. http://www.asean.org/asean/about-asean/

70 The Trans-Pacific Partnership (TPP) is a free trade agreement that will liberalize trade and investment between 12 Pacific-rim countries: New Zealand, Australia, Brunei Darussalam, Canada, Chile, Japan, Malaysia, Mexico, Peru, Singapore, the United States and Viet Nam. Trade Ministers of the 12 Asia Pacific countries negotiating the Trans-Pacific Partnership (TPP) have announced the formal conclusion of negotiations. Read the Ministerial announcement made in Atlanta on 5 October 2015.

https://www.mfat.govt.nz/en/trade/free-trade-agreements/free-trade-agreements-concluded-but-not-in-force/tpp/

${ }^{71}$ Regional Comprehensive Economic Partnership (RCEP) is a critical element in regional integration in East Asia and the Pacific. RCEP takes initiatives on regional economic integration in East Asia to a higher level. First, in contrast with the ASEAN+1 free trade agreements (FTAs) where individual ASEAN member states had essentially bilateral commitments with the ASEAN+1 dialogue partners, ASEAN member states would likely need to have common commitments vis-à-vis the partners (with perhaps a few exceptions) under RCEP. Second, the commitments of the dialogue partners need to be common commitments congruent with those of ASEAN member states. Third, the commitments under RCEP need to be substantially better than those under the ASEAN+1 FTAs; in short, RCEP should not merely by consolidation of the ASEAN+1 FTA commitments for the simple reason that mere consolidation is only feasible at the lowest common denominator that delivers far less than several the ASEAN+1 FTAs. Given that RCEP effectively includes an implicit FTA among China, Japan, and South Korea which results in trade and investment.

diversion from ASEAN compared with the ASEAN+1 FTAs, only improved non-tariff measures and deeper trade and investment facilitation would provide additional benefits to ASEAN member states as compared to the current ASEAN+1 FTAs. Lili Yan Ing, Economic Research Institute for ASEAN and East Asia, 2015. 
costs over four years until 2006. To implement this, the APEC Trade Facilitation Principles were endorsed in close participation with the private sector. The second phase of the TFAP was launched in 2007, with the objective of implementing a further 5 percent reduction in transaction costs. APEC Members' Trade Facilitation Plans concentrated on border issues such as customs facilitation, APEC travel card, and facilitation of the movement of goods via the adoption of harmonized standards and Mutual Recognition Agreements. In 2009, APEC moved beyond reducing transaction costs and expanded its trade facilitation work to cover other associated transport, communication and related regulatory-behind-the-border costs, including trade logistics, in the region's trade facilitation agenda. This forum realized that in the current economic environment, businesses seek short transit times, reliable delivery schedules, careful handling of goods, certification of product quality, and security from theft. After receiving inputs from the private sector, APEC Members developed their Supply Chain Connectivity Framework Action Plan in 2009. The SCFAP was developed to counteract eight critical supply chain "chokepoints".

These chokepoints are the following: 1) lack of transparency/awareness of the full scope of regulatory issues affecting logistics; lack of awareness and coordination among government agencies on policies affecting the logistics sector; absence of a single contact point or "champion agency" on logistics matters: 2) inefficient or inadequate transport infrastructure; lack of crossborder physical linkages (e.g. roads, bridges); 3) lack of capacity of local/regional logistics subproviders; 4) inefficient clearance of goods at customs; lack of coordination among border agencies, especially in connection with clearance of regulated goods "at the border"; 5) burdensome customs documentation and other procedures (including in preferential trade); 6) underdeveloped multimodal transport capabilities; inefficient air, land, and multimodal connectivity; 7) variations in cross-border standards and regulations for the movement of the goods, services and business travelers; and 8) lack of regional cross-border customs-transit arrangements.

The core objective of the above efforts is to reduce trading times, costs and uncertainty by 10 percent by 2015. APEC now focuses on three main areas that will merge with the regional connectivity agenda: 1) improving reliability by reducing supply chain uncertainty, characterized by the lack of consistency in supply chain transit time around which users have organized their activities; 2) building awareness of the risks of connectivity; and 3) higher visibility through the creation of an information-sharing platform that could ensure real-time integrity of the data (Basu Das, S, Phuong Thao, P.T. and James, C. R., 2013).

The 2013 Interim Assessment for the Supply Chain Connectivity Framework Action Plan pointed out that: first, in terms of time, APEC economies have been quite successful in reducing trade times by nearly 7\% (using Doing Business data on export time and LPI data on import time). Second, in terms of costs, there is some indication of a cost increase, which would be explained by unexpected supply chain disruptions due to natural events such as earthquakes and floods. Third, in terms of uncertainty based on the percentage of shipments meeting firm quality criteria from the LPI, there has been an increase of about $4 \%$ over 2009-2011. The percentage of shipments 
that are physically inspected also showed significant improvement and met the interim target. Collectively, this could be interpreted to imply a similar reduction in the level of supply chain management uncertainty.

The 2013 APEC Leaders' Declaration emphasized the goal of reaching a seamlessly and comprehensively connected and integrated Asia-Pacific region through the pillars of Physical Connectivity, Institutional Connectivity, and People-to-People Connectivity (APEC Policy Support Unit (PSU), 2014). In this regard, they developed the APEC Connectivity Blueprint for 2015-2025. Regarding trade, transport and logistics facilitation under the Institutional Connectivity umbrella, they indicated the need to make progress in jointly addressing issues of trade facilitation, structural and regulatory reforms, as well as transport and logistics facilitation, which are of critical importance to APEC as a regional forum. Institutional connectivity addresses trade facilitation issues and improves the coherence and interoperability of its institutions, mechanisms, and processes. This subject, known as "soft infrastructure", covers trade and investment policies and agreements, as well as institutional links to support greater coherence of regulations and regional cooperation. The discussion paper on connectivity framework (2013/SOM2/SYM/003) defines institutional connectivity to cover behind-the-border issues, including structural and regulatory reforms, and points out that more recent agenda items include transport and logistics facilitation (APEC Policy Support Unit (PSU), 2014).

This commitment was underpinned in the $22^{\text {nd }}$ APEC Economic Leaders Declaration (China, 2014), which strengthened the initiatives under the APEC Supply-Chain Connectivity Framework Action Plan by systematically improving supply chain performance through a capacity-building plan to assist economies in overcoming specific obstacles within the eight chokepoints of the SCFAP. They created the APEC Alliance for Supply Chain Connectivity (A2C2), an entity which brings together the expertise and resources of the private sector, multilateral institutions, and non-governmental organizations in supply chain connectivity work.

Epictetus Patalinghug (Patalinghug, 2015) recommends the following steps in APEC's future agenda for further enhancing its Supply Chain Connectivity initiative:

- Encouraging regional cooperation by establishing and nurturing the policy environment for new regional infrastructure projects.

- Promoting initiatives in support of APEC Principles of Trans-Border Logistics. These principles, issued in 2011, are the following: Transparency, Consistency, Simplicity, Efficiency, Harmonization, Standardization, Interagency Coordination, and Cooperation (APEC, 2011).

- $\quad$ Optimizing services, including by simplifying and harmonizing trade and transportation procedures and practices.

- $\quad$ Building the capacity of local logistics providers and SMEs by facilitating their access with multinational logistics corporations. 
- Addressing customs impediments in APEC Cross-Border Customs-Transit Arrangements, including by changing customs documentation standards and inadequate IT infrastructure.

- Encouraging member economies to establish stronger engagements with the relevant stakeholders to identify specific problems faced by each member.

He above supply-chain perspective was also adopted by the ASEAN member states. ASEAN's vision has evolved to treat logistics as a part of the core integration agenda. The 2007 Roadmap for the Integration of Logistics Services effectively designates logistics as an additional priority sector (ADA). The ASEAN roadmap recognizes this by identifying five core principles, which can be developed into detailed sets of actions and time frames: i) progressive liberalization of transport and logistics services sectors; ii) enhanced competitiveness of ASEAN logistics providers through trade and logistics facilitation; iii) expanded capability of logistics services providers in ASEAN; iv) development of human capacities in logistics; and v) upgraded multimodal transport infrastructure and investment (ASEAN, 2007).

According the ADA, ASEAN's approach is remarkable for its ambitious goals. It covers both physical and regulatory infrastructure; and goes further by addressing the need to invest in sector-specific human capital. Each of the principles set out above is used as an organizing concept for a set of specific policy goals, each of which has a designated implementing agency within ASEAN and a timeline for implementation. (ASEAN, 2007)

The ADA remarks that ASEAN's experience in enhancing the performance of the group's logistics sector as part of broader regional integration agenda suggests several useful lessons for policy makers. These include the following: i) an enhanced logistics sector with the potential to significantly boost regional and international trade; ii) a broad-based reform of the logistics sector, covering sector-wide regulations, infrastructure, and the general trading environment; iii) the general principles should be backed by detailed and precise commitments, attribution of responsibility to implementing agencies, and verifiable timelines; iv) an effective coordination of actors at the national and international levels is vital to the success of reforms, given the dispersion of responsibilities and expertise across agencies. (ASEAN, 2007)

In 2010, ASEAN Leaders adopted the Master Plan on ASEAN Connectivity (MPAC). Connectivity is crucial for physical, institutional and people-to-people connectivity, not only to reduce business transaction costs, time and travel costs, but also to connect the "core" and the "periphery" in ASEAN, thus distributing the benefits of multi-faceted growth more widely in the region and reducing the development divide in ASEAN (ASEAN, 2011).

The MPAC thus has a three-pronged strategy for enhancing connectivity:

Physical connectivity: This includes land and maritime transport, ICT, and energy infrastructure. Currently, in ASEAN, the physical infrastructure, particularly in the less developed members, is 
characterized by structural weaknesses. Most ASEAN countries are also short of soft "infrastructure" (ICT), which is an important prerequisite for the next step of development. This calls for the upgrading of existing infrastructure, the construction of new infrastructure and the harmonization of regulatory frameworks (ASEAN, 2011).

Institutional connectivity: This relates to free flow of goods and investment and transport facilitation. ASEAN countries continue to struggle with the issue of non-tariff barriers (NTBs) to trade and investment. While some such barriers are necessary - for example, to protect the environment or the health of the humans, animals or plants - others unnecessarily distort trade flows and restrict competition. To address this, ASEAN needs to harmonize standards and conformity assessment procedures, and operationalize key transport facilitation agreements to reduce the cost of moving goods across the borders. In addition, ASEAN member states must fully implement their respective National Single Windows plans towards completing the ASEAN Single Window initiative by 2015 (ASEAN, 2011).

People-to-people connectivity: This entails deeper intra-ASEAN cultural interaction, greater intraASEAN people mobility through the progressive relaxation of visa requirements and the development of mutual recognition arrangements (MRAs) to facilitate ongoing efforts to increase greater interactions between ASEAN peoples (ASEAN, 2011).

The ASEAN Leaders decided the establishment of an ASEAN Community (AEC) in 2015 (2003 9th ASEAN Summit and 2007 12th ASEAN Summit). The AEC is founded on four basic initiatives: creating a single market and production base; increasing competitiveness; promoting equitable economic development; and further integrating ASEAN with the global economy. The ASEAN Economic Community Blueprint 2025 (AEC 2025) stipulates some guidelines in the trade, transport and logistics facilitation topics. This document has as a main objective to facilitate the seamless movement of goods, services, investment, capital, and skilled labor within ASEAN to enhance ASEAN's trade and production networks (ASEAN, 2015). The AEC 2025 envisages, among other objectives, to widen ASEAN people-to-people, institutional, and infrastructure connectivity through ASEAN and sub-regional cooperation projects that facilitate the movement of capital, as well as skilled labor and talents (ASEAN, 2015). Enhanced connectivity is highlighted as a main objective of this regional integration scheme (ASEAN, 2015).

Programs of trade capacity building are established in FTAs between ASEAN members and their partners. Marn-Heong Wong and Claire H. Hollweg highlight that, under the services component of the ASEAN-Australia-New Zealand Free Trade Area Economic Cooperation Work Program, a project on Technical Assistance to Enhance ASEAN Logistics Services Sector is being implemented (Wong, M. and Hollweg, C., 2015). The same authors indicate that transport and logistics is one of the fields of economic cooperation in the ASEAN-Japan Comprehensive Economic Partnership agreement, and the partners are implementing the logistics capacity-building program under the ASEAN-Japan Transport Logistics Improvement Plan (Wong, M. and Hollweg, C., 2015). 
Beyond trade capacity building programs, ASEAN's trade in services agreements with its FTA partners -Australia-New Zealand, China and South Korea- also include liberalization commitments in services sectors that are part of logistics services (Wong, M. and Hollweg, C., 2015).

In their assessment of the implementation of the MPAC, Duong Anh Nguyen and Thanh Tri Vo indicates that this master plan seems to focus more on the development of infrastructure (i.e. physical connectivity). They point out that there are quite a few more elements under physical connectivity than under institutional connectivity and people-to-people connectivity in terms of strategies, key actions, and prioritized projects (Nguyen, A. and Tri Vo, T., 2015). These authors conclude that the overarching objective of MPAC is well elaborated, with support and feasibility embodied in several strategies and key actions plans. However, from their perspective, MPAC implementation may be subject to several challenges, an imbalance in its focus, lack of coordination among projects, and limited sources of finance and monitoring mechanisms (Nguyen, A. and Tri Vo, T., 2015).

Shintaro Hamanaka and Ben Sherpherd underscore ASEAN's emphasis on integration as a good example of setting a commercially meaningful scope of logistics, covering both logistics services and customs-related issues. They also see implementation problems in this regional scheme. Both analysts highlight the importance of capacity building in logistics for SME's (Hamanaka, S. and Shepherd, B., 2015). Regarding the Asian Economic Community Blueprint, they say that this document focuses on reducing public sector barriers to international logistics markets, on the assumption that private operators will then take advantage of the newly created commercial opportunities to increase trade and investment (Hamanaka, S. and Shepherd, B., 2015).

As there may be overlapping between APEC and ASEAN logistics policies, Sanchita Basu Das, Pham Thi Phuong Thao, and Catherine Rose James call attention to areas of mutual interest and prospects of cooperation between APEC and ASEAN in connectivity. The subjects where APEC could collaborate with ASEAN include: supply chain connectivity, trade facilitation, investment, disaster management, structural reforms, food security and small and medium enterprises (Basu Das, S, Phuong Thao, P.T. and James, C. R., 2013).

At the sub-regional level, there are many integration schemes which adopt a supply chain perspective combining trade facilitation, logistics, and transport facilitation. In the case of the Greater Mekong Sub-region (GMS), for instance, the approach to trade cost reduction is improving regional connectivity, first through the creation of transport corridors programs, followed by the provision of regulatory support to regional infrastructure development through the GMS crossborder transit agreement (CBTA). The transport corridors program has developed transport networks throughout the sub-region to increase trade volumes within and outside the GMS. The CBTA covers customs and border formalities, exchanges of commercial traffic rights, transit regimes, infrastructure standards, and vehicle requirements for cross-border traffic. (Asian 
Development Bank/United Nations Economic and Social Commission for Asia and the Pacific, 2013)

Another example is the Central Asia Regional Cooperation Economies (CAREC) initiative for reducing trade through an ambitious program of trade facilitation and transport. The CAREC Joint Transport and Trade Facilitation Strategy developed priority corridors, which were focused on improvements in trade facilitation measures, thereby creating synergies in trade cost reduction.

The Brunei Darussalam and border areas of Indonesia, Malaysia, and the Philippines (BIMP-EAGA) offer another pattern of coordinating trade facilitation policies with logistics services and transport facilitation. The goal of breaking the vicious cycle of low trade volumes - no connectivity - is approached by sequencing reforms. Fragmented supply chains and improvements in trade facilitation measures are first addressed, followed by the development of transport networks. This sequence of reforms results from an analysis aimed at identifying critical constrains to integration and trade. The approach to developing the potential sub-regional economic corridor in the Pacific is building border relations with neighbors, covering border management and border infrastructure and services.

Mega-regional trade agreements also address supply chain competitiveness topics. Negotiations for establishing the TPP, called the "21st century trade agreement", included supply chains issues. This new topic was promoted especially by the private sector. The U.S. Chamber of Commerce plan points out to modernizing global supply chains. This business community demands the following to the U.S. public sector ${ }^{72}$ :

- Promoting trade facilitation and customs modernization to enable an efficient movement of goods throughout the global supply chain.

- Engaging Congress to issue supply chain and trade facilitation legislation that includes business solutions to logistics, cross-border, and customs facilitation issues.

- Reversing thickening border trends and promoting security cooperation through a multi-layered, risk-based approach with trade partners to ensure that mandates do not restrain legitimate trade.

- Promote global convergence of cross-border transportation, security, customs processes and regulation to enhance the efficient transport in trade activities.

- Aggressively respond to regulations and legislation that restrain supply chain facilitation and trade.

- Working with the U.S. Trade Representative, all countries in the negotiation, and member companies to promote trade facilitation, efficient supply chains, and rational customs principles within the Trans-Pacific Partnership, the Transatlantic Trade and

\footnotetext{
72 US Chamber of Commerce (2016) Global Supply Chain, Customs and Trade Facilitation https://www.uschamber.com/issue-brief/global-supply-chain-customs-and-trade-facilitation, acceded February $1^{\text {st. }}$ 2016.
} 
Investment Partnership and the World Trade Organization's Trade Facilitation Agreement.

- Ensuring public and private sector cooperation when identifying threats and creating appropriate solutions to maximize the impact on security and minimize the impact on business and trade.

- Advancing customs modernization and international best practices to achieve transparent and effective regulatory standards for products in the global supply chain.

The Asia-Pacific business community requested to TPP leaders to reach to a high standard agreement regarding supply chain competitiveness. They demanded innovative solutions, with concrete new commitments on new generation and behind-the-border issues, including eliminating chokepoints in the operation of regional supply and value chains, fostering small and medium sized business participation in expanding trade, facilitating regulatory coherence, and promoting and protecting innovation ${ }^{73}$.

TPP supply chain negotiations were conceived as a stand-alone chapter, and were emphasized in other chapters covering supply chain-related issues. Ian F. Fergusson, Mark A. McMinimy, and Brock R. Williams indicate that the broad range of issues affecting supply chains involve many chapters already included in U.S. FTAs include harmonization of standards; adequate infrastructure (ports, roads, etc.) to facilitate trade; simplification of rules of origin; and greater customs efficiency (Fergusson, I., McMinimy, M. and Williams, B., 2015).

Although the U.S. supported the supply chain stand-alone chapter, this proposal was rejected by the others TPP partners. As a substitute, in the final text, supply chain competitiveness is treated as a horizontal issue. It is mentioned in the preamble as follows: "strengthen the competitiveness of their businesses in global markets and enhance the competitiveness of their economies by promoting opportunities for businesses, including promoting the development and strengthening of regional supply chains".

Besides, there is an article included in the chapter on competitiveness and business facilitation. The latter identifies the development and strengthening of regional supply chains as an objective of the TPP agreement. It establishes a basic framework for the Committee to assess supply chain performance under the TPP, including submission of reports to the TPP Parties with findings and recommendations; consideration of ways to promote TPP small- and medium-sized enterprise (SME) participation in supply chains; review of stakeholder and expert input; and regularly scheduled meetings ${ }^{74}$.

\footnotetext{
${ }^{73}$ Media statement, November 10, 2011 ASIA PACIFIC BUSINESSES URGE TPP LEADERS TO COMMIT TO CONCLUSION OF COMPREHENSIVE, HIGH-STANDARD TPP IN 2012

${ }^{74}$ TPP article 22.3 and The USTR website: TPP Made in America, Chapter 22. https://medium.com/the-trans-pacificpartnership/competitiveness-and-business-facilitation-6260e31f17fa\#.salf3jbkn
} 
At the beginning of the RCEP, in the 'Guiding Principles and Objectives for Negotiating the RCEP' endorsed by RCEP Ministers on 30 August 2012, the RCEP will "include provisions... to facilitate the participating countries' engagement in global and regional supply chains" (Wong, M. and Hollweg, C., 2015). Given the critical role of logistics services in ensuring well-functioning supply chains, RCEP members should give priority to the logistics services sector. Taking into consideration this observation, RCEP members may want to broaden the coverage to include more sub-sectors in the various tiers of logistics services and adopt a comprehensive definition of logistics services that corresponds to the industry's characteristics and needs, as well as a single set of liberalization commitments (Wong, M. and Hollweg, C., 2015).

Marn-Heong Wong and Claire H. Hollweg point out that, as an ASEAN-led initiative, it can first and foremost adopt the elements in ASEAN's Roadmap for the Integration of Logistics Services and build on the experience of ASEAN members in implementing the roadmap. Moreover, as the negotiations phase has not yet been completed, it would be advisable to include a supply chain competitiveness stand-alone chapter (Wong, M. and Hollweg, C., 2015).

Experience in the Asia-Pacific should serve Peru and Chile, as they start to implement their national logistics policies, in gaining competitiveness at the regional level. Considering that both countries are members of the Pacific Alliance and the TPP, they should submit proposals in these forums aimed at developing logistics providers in both countries. While negotiations in terms of logistics are just taking shape, it would be a good opportunity for both countries to become dominant players in this field. 


\section{Conclusions}

Both Chile and Peru are becoming aware of the importance of logistics as a fundamental tool for the enhancing competitiveness. The initial diagnosis in both cases due teaches design appropriate public policies for developing logistics nationwide.

Comparatively speaking, Peru is behind Chile in infrastructure development. However, the creation and maintenance of infrastructure at OECD levels should be taken as a standard in development of national logistics plans.

As a first step for developing a national logistics system, both countries should take stock of the current situation. In Peru, many documents contain important institutional and legal considerations for launching a national logistics plan. In contrast, in Chile the supporting documentation is less abundant and apparently, there is not yet an independent modal transportation vision in place. In conclusion, all the logistics development is analyzed together with the port.

Like throughout the region, the fragmentation of the relevant authorities and regulation is one of the main barriers to logistics development. Peru has developed a specific model of governance, but associated law has not yet been implemented.

Chile stands out as a leader in the provision of logistics services in the region. Peru is behind, but both countries are far from meeting OECD standards. This indicates that both countries will need to devise a mechanism for logistics service providers to comply with industry standards globally.

The lack of development of multimodal transport appears to be an explanation for the weak presence of world-class logistics operators.

Logistics service providers are regulated primarily from the customs point of view. There is no scheme for promoting national development. Chile's experience of considering logistics services as export activities could be an indicator of how to work systematically to meet the policy objectives for developing logistics service providers.

A consistent progress in the development of the logistics industry for both countries requires that, once a national logistics system is implemented, the institutions should point to a public-private dialogue that will lead to a concrete short- and medium-term strategic plan. 


\section{Bibliography}

Advanced Logistics Group. (2009). Study aimed at regulating the allocation of responsibilities in port services and related study provided to the load. Proyecto UE-Perú/PENX Mincetur.

Alog Chile Asociación Logística AG. (n.d.). Agenda Logística País.

Antún, \& Alarcón. (2015). Estudios de caso de terminales de carga aérea en aeropuertos de países miembros de la unión de naciones de Suramérica (UNASUR). -: Banco Interamericano de Desarrollo (BID).

APEC. (2011). Transborder Control and Optimal Transborder Logistics Final Report, APEC Transportation Working Group and APEC Committee on Trade and Investment.

APEC Policy Support Unit (PSU). (2014). APEC Connectivity Blueprint.

Apoyo Consultoria. (2015). Study on the measurement of the degree of competition between ports in the port of Callao terminal.

ASEAN. (2007). 2007 Asean Sectoral Integration Protocol for the Logistics Services Sector. Appendix 1 Roadmap for the Integration of Logistics Services.

ASEAN. (2011). Master Plan on ASEAN Connectivity.

ASEAN. (2015). The ASEAN Economic Community Blueprint 2025.

Asian Development Bank/United Nations Economic and Social Commission for Asia and the Pacific. (2013). Chapter 4. Trade: Trade-Related Infrastructure and Services. In Asian Development Bank/United Nations Economic and, Designing and Implementing Trade Facilitation in Asia and the Pacific 2013 Update.

Banco Interamericano de Desarrollo. (2013). Formulación y Gestión de Políticas sobre Logística Edición 1. Módulo 2: La Oferta- Los compónentes del Sistema Logístico Nacional. Banco Interamericano de Desarrollo.

Banco Interamericano de Desarrollo. (2013). Formulación y Gestión de Políticas sobre Transporte de Carga y Logística. MODULO 1: La logística de Cargas y los Sistemas Logísticos Nacionales. Banco Interamericano de Desarrollo.

Basu Das, S, Phuong Thao, P.T. and James, C. R. (2013). APEC and ASEAN Connectivity: Areas of Mutual Interest and Prospects of Cooperation. ISEAS Perspective № 28, Singapore.

Brooks, M.; Pallis, T. and Perkings, S. (2014). Port Investment and Container Shipping Markets. Round Table Summary and Conclusions № 3 International Transport Forum. 
Comisión Estrategia 2030 de Puertos y Logística 2030. (2015). Logística y Puertos: Una plataforma estratégica de desarrollo para Chile. Santiago: Comisión Estrategia 2030 de Puertos y Logística 2030.

Comisión Estrategia 2030 de Puertos y su Logística. (2015). Logística y Puertos: Una plataforma estratégica de desarrollo para Chile.

Consorcio Modernización Portuaria. (2011). Estudio de costos y sobrecostos en los terminales portuarios de uso público.

Consultoría, A. (2015). Estudio sobre la medición del grado de competencia intraportuarioa en el TPC.

Fergusson, I., McMinimy, M. and Williams, B. (2015). The Trans-Pacific Partnership (TPP) Negotiations and Issues for Congress. Congressional Research Service, R42694.

García Cobos, J. (2005). Estudio sobre las condiciones de competencia en los mercados de servicios a la carga en el puerto de El Callao.

Goh, M. (2013). Connectivity pertains to the sustained ability to link different actors and arcs or trade flows in the supply chain to ensure that goods and services can flow freely from one location to another. In D. K. Low, Supply chain connectivity and trade in Asia. Global value chains in a changing world. Fung Global Institute (FGI), Nanyang Technological University (NTU), and the World Trade Organization (WTO).

Guerrero, P., Lucenti, K., \& Galarza, S. (2009). Trade Logistics and Regional Integration in Latin America \& the Caribbean. Inter-American Development Bank.

Hamanaka, S. and Shepherd, B. (2015). Overcoming Trade Logistics Challenges: Asia-Pacific Experiences, Developing Trade Consultants.

Hamanaka, S., \& Shepherd, B. (2015). Overcoming Trade Logistics Challenges: Asia Pacific Experiences. New York: Asia-Pacific Journal of Marketing and Logistics.

Hickson, A., Wirth, B. and Morales, G. (2008). Supply Chain Intermediaries. University of Manitoba Transport Institute. Manitoba.

Hoeckman B. and Jackson S. (2013, January 23). Reinvigorating the trade policy agenda: Think supply chain! Retrieved from VOX CEPR's Policy Portal: http://voxeu.org/article/reinvigorating-trade-policy-agenda-think-supply-chain

Hoekman, B. (2014). Supply Chains, Mega-Regionals and Multilateralism: A Road Map for the WTO. EUI Working Paper RSCAS 2014/27. 
Hoekman, B. (n.d.). A 21st Century Trade Agenda: Global Supply Chains and Logistics Services. Retrieved from World Trade Organization:

https://www.wto.org/english/forums_e/public_forum12_e/art_pf12_e/art5.htm

Jaimurzina, A., Pérez Salas, G. y Sánchez, R. (2015). Políticas de logística y movilidad para el desarrollo sostenible y la integración regional. Serie Recursos Naturales e Infraestructura No. 174. CEPAL.

Korinek, J., \& Sourdin, P. (2011). To what extent are high-quality logistics services trade facilitating? OECD Publishing.

Kunaka, C., Mustra, M. A., \& Saez, S. (2013). Trade Dimensions of Logistics Services. The World Bank.

Mangan J., Lalwani Ch., Butcher T. and Javadpour, R. (2012). Logistics Services Providers. Chapter 8. In Global Logistics and Supply Chain Management. John Wiley \& Sons, Ltd.

Michea, A. (2014). Programa de Desarrollo Logístico. Ministerio de Transportes y Comunicaciones. Taller sobre Carga y Logístico del BID.

Michea, A. (2014). Programa de Desarrollo Logítico. Santiago de Chile: Ministerio de Transportes y Telecomunicaciones.

Ministerio de Obras Públicas. (2009). Infraestructura portuaria y costera: Chile 2020. Santiago: Ministerio de Obras Públicas.

Ministry of Transport and Communications. (2012). Inmediate Action Plan, The Development Plan of the Logistics Services Plan of Medium and Long Term. General Office Planning and Budget.

Ministry of Transport and Communications, I.-A. D. (2011). The Development Plan of the Logistics Services of Transports, Part -A-Diagnosis Final Chapter 8.

Ministry of Transport and Communications, Inter American Development Bank and Advanced Logistics Group. (2014). Plan for the Development of Transport Logistics Services Plan of Medium and Long Term.

Ministry of Transport and Communications, Inter-American Development Bank and Advanced Logistics Group. (2011). The Development Plan of the Logistics Services of Transports, Part -A-Diagnosis Final Chapter 8.

Nadramija, N. (2013). Informe Final. Evaluación comparada del impacto económico como resultado de aplicar las reglas de La Haya de 1924 y las reglas de Hamburgo de 1978 en el flete marítimo.

National Competitiveness Council. (2015). The Competitiveness Council. 
Nguyen, A. and Tri Vo, T. (2015). Enhancing East Asian Connectivity: What Can Asean and Japan Do? In R. S. Soeya, Navigating Change: Asean - Japan Strategic Partnership in East Asia and Global Governance. Tokyo: Japan Center for International Exchange.

OECD. (2015). OECD Economic Surveys Chile.

Patalinghug, E. (2015). Supply Chain Connectivity: Enhancing Participation in the Global Supply Chain. Discussion Paper Series № 2015, Philippine Institute for Development Studies.

Pérez Salas, G. (2013). Recursos naturales e infraestructura. Seguridad de la cadena logística terrestre en América Latina. Santiago de Chile: CEPAL.

Pontifical Catholic University of Valparaíso. (2011). Study logistics competitiveness of Chilean foreign trade: proposals to unlock, reduce costs and modernize public policies in the sector.

Saslavsky, D. and Shepherd, B. (2012). Facilitating International Production Networks: The Role of Trade Logistics, Policy Research Working Paper 6224.

SELA-ACICl. (2008). Cooperación Internacional para la Facilitación del comercio en América Latina y el Caribe: Hacia un Programa Regional. XIX Reunión de Directores de Cooperación Internacional de América Latina y el Caribe, (p. 55). México.

Sugie, K. e. (2015). Services Trade Restrictiveness Index. Paris: OECD Trade Policy Papers.

Sugie, K. e. (2015). Services Trade Restrictiveness Index (STRI): Logistics Services. OECD Trade Policy Papers № 183, OECD Publishing, Paris.

The World Bank. (2016). Comprehensive analysis of Logistics in Peru. Part 1.

UNASUR. (2012). UNASUR: Infrastructure for regional integration. Santiago de Chile: UNASUR.

UNCTAD. (2006). Managing the Request-Offer Negotiations under the GATS: Logistics services.

UNCTAD. (2013). Peru Services Policy Review UNCTAD/DITC/TNCD/2013.

UNESCAP. (2013). Guide to Key Issues in Development of Logistics Policy.

Universidad del Pacífico. (unkwon). El mercado de Almacenamiento Aduanero en el terminal aéreo del Callao.

Wong, M. and Hollweg, C. (2015). 12 Regulatory restrictions in logistics services of ASEAN + 6 economies. In C. Findlay, ASEAN and Regional Free Agreements. Routledge and the Economic Research Institute for ASEAN and East Asia (ERIA).

World Bank. (2016). Connecting to Compete 2016. Trade Logistics in the Global Economy.

World Economic Forum. (2013). Enabling Trade Valuing Growth Opportunities. 
World Economic Forum. (2016). The Global Competitiveness Report 2015-2016.

World Trade Organization. (2015). WTO Trade Policy Review. Report by the Secretariat. $W T / T P R / S / 315$.

WTO/OECD. (n.d.). Aid for trade and value chains in transport and logistics. WTO/OECD. 